Prepared in cooperation with the Federal Emergency Management Agency

\title{
Flood Recovery Maps for the White River in Bethel, Stockbridge, and Rochester, Vermont, and the Tweed River in Stockbridge and Pittsfield, Vermont, 2014
}

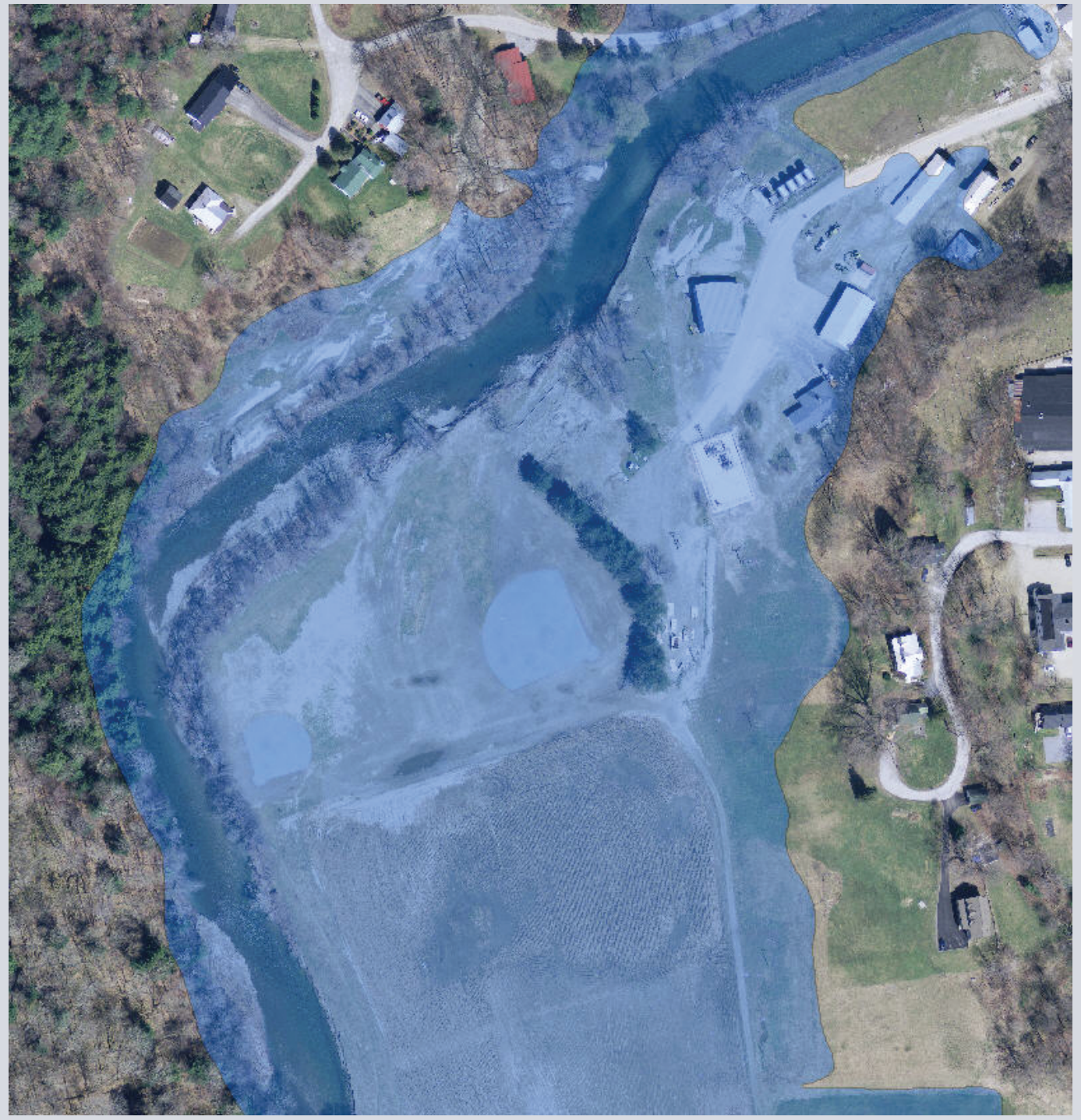

Scientific Investigations Report 2015-5056 
Cover. One-percent annual exceedance probability flood boundaries on the White River in the Rochester, Vermont, vicinity. 


\section{Flood Recovery Maps for the White River in Bethel, Stockbridge, and Rochester, Vermont, and the Tweed River in Stockbridge and Pittsfield, Vermont, 2014}

By Scott A. Olson

Prepared in cooperation with the Federal Emergency Management Agency

Scientific Investigations Report 2015-5056 


\title{
U.S. Department of the Interior SALLY JEWELL, Secretary
}

\section{U.S. Geological Survey Suzette M. Kimball, Acting Director}

\author{
U.S. Geological Survey, Reston, Virginia: 2015
}

For more information on the USGS - the Federal source for science about the Earth, its natural and living resources, natural hazards, and the environment-visit http://www.usgs.gov/ or call 1-888-ASK-USGS.

For an overview of USGS information products, including maps, imagery, and publications, visit http://www.usgs.gov/pubprod/.

Any use of trade, firm, or product names is for descriptive purposes only and does not imply endorsement by the U.S. Government.

Although this information product, for the most part, is in the public domain, it also may contain copyrighted materials as noted in the text. Permission to reproduce copyrighted items must be secured from the copyright owner.

Suggested citation:

Olson, S.A., 2015, Flood recovery maps for the White River in Bethel, Stockbridge, and Rochester, Vermont, and the Tweed River in Stockbridge and Pittsfield, Vermont, 2014: U.S. Geological Survey Scientific Investigations Report 2015-5056, 32 p., http://dx.doi.org/10.3133/sir20155056.

ISSN 2328-0328 (online) 


\section{Acknowledgments}

The author wishes to thank the following U.S. Geological Survey personnel who assisted with the collection of data in this report: Adam Hudziec, Andrew Massey, Lance Ostiguy, Kelseyann Regan, Thor Smith, Jason Sorenson, and Marc Zimmerman. The author also would like to acknowledge that the light detection and ranging data collected throughout the study reaches and used for the digital elevations model was funded by the Vermont Agency of Transportation. 



\section{Contents}

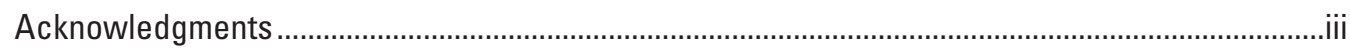

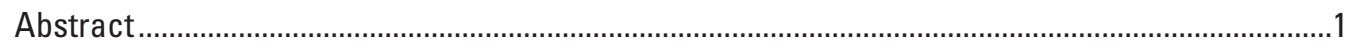

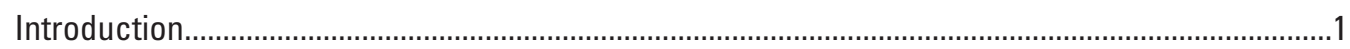

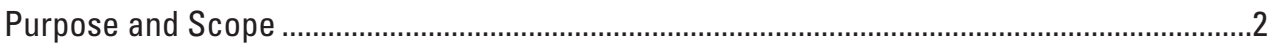

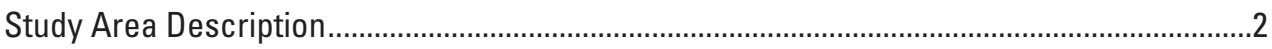

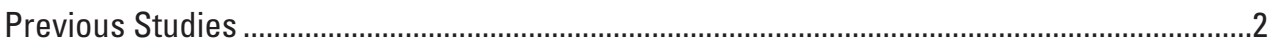

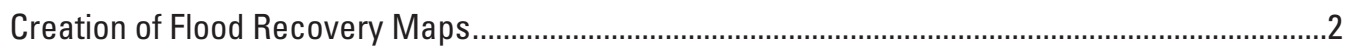

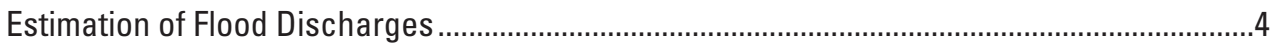

Topographic and Bathymetric Data .....................................................................................

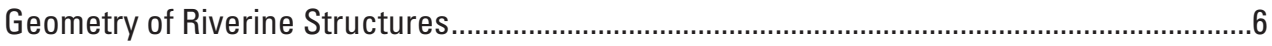

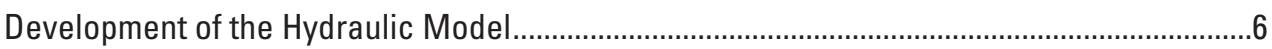

Annual Exceedance Probability of Flooding From Tropical Storm Irene....................................7

Development of Flood Recovery Maps ..........................................................................

Uncertainties and Limitations Regarding Use of Flood Recovery Maps ...........................................8

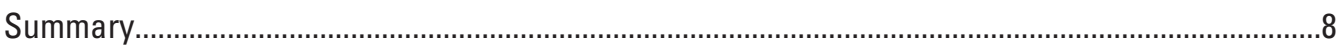

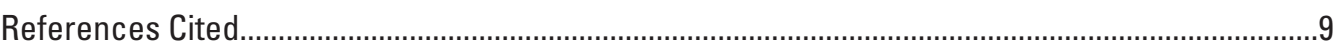

Appendix 1. Flood Recovery Maps at Selected Annual Exceedance Probabilities for the White and Tweed Rivers in Bethel, Stockbridge, Pittsfield, and Rochester, Vermont.........11

Appendix 2. Water-Surface Elevations for Selected Annual Exceedance Probabilites for the White River in Bethel, Stockbridge, and Rochester, Vermont, and Tweed River in Stockbridge and Pittsfield, Vermont....................................................................................13

Appendix 3. Water-Surface Elevations for Selected Annual Exceedence Probabilities for the White River Modified for the Planned Route 73 Bridge in Rochester, Vermont............21

Appendix 4. Results of the Floodway Analysis for the White River in Bethel, Stockbridge, and Rochester, Vermont, and the Tweed River in Stockbridge and Pittsfield, Vermont.....23

Appendix 5. Results of the Floodway Analysis for the White River Modified for the Planned Route 73 Bridge in Rochester, Vermont...........................................................................31

\section{Figure}

1. Map showing location of the White and Tweed River study reaches in Bethel, Stockbridge, Pittsfield, and Rochester, Vermont.

\section{Tables}

1. Flood discharges used in the hydraulic model for the White River in West Hartford, Bethel, Stockbridge, and Rochester, Vermont.

2. Flood discharges used in the hydraulic model for the Tweed River and South Branch Tweed River in Stockbridge and Pittsfield, Vermont

3. Comparison of simulated water-surface elevations to observed high-water marks at selected locations along the White and Tweed River study reaches for Tropical Storm Irene, August 27-28, 2011. 


\section{Conversion Factors}

Inch/Pound to International System of Units

\begin{tabular}{lll}
\hline \multicolumn{1}{c}{ Multiply } & By & \multicolumn{1}{c}{ To obtain } \\
\hline inch (in.) & Length & \\
foot (ft) & 2.54 & centimeter $(\mathrm{cm})$ \\
mile (mi) & 0.3048 & meter $(\mathrm{m})$ \\
\hline & 1.609 & kilometer $(\mathrm{km})$ \\
\hline square mile $\left(\mathrm{mi}^{2}\right)$ & Area & \\
\hline & 2.590 & square kilometer $\left(\mathrm{km}^{2}\right)$ \\
\hline cubic foot per second $\left(\mathrm{ft}^{3} / \mathrm{s}\right)$ & Flow rate & \\
\hline
\end{tabular}

\section{Datum}

Vertical coordinate information is referenced to (1) stage, the height above an arbitrary datum established at a streamgage, and (2) elevation, the height above the North American Vertical Datum of 1988 (NAVD 88).

Horizontal coordinate information is referenced to the North American Datum of 1983 (NAD 83).

Elevation, as used in this report, refers to the distance above the vertical datum. 


\title{
Flood Recovery Maps for the White River in Bethel, Stockbridge, and Rochester, Vermont, and the Tweed River in Stockbridge and Pittsfield, Vermont, 2014
}

\author{
By Scott A. Olson
}

\section{Abstract}

From August 28 to 29, 2011, Tropical Storm Irene delivered rainfall ranging from about 4 inches to more than 7 inches in the White River Basin. The rainfall resulted in severe flooding throughout the basin and significant damage along the White River and Tweed River. In response to the flooding, the U.S. Geological Survey, in cooperation with the Federal Emergency Management Agency, conducted a new flood study to aid in the flood recovery and restoration. This flood study includes a 20.7-mile reach of the White River from the downstream end at about 2,000 feet downstream from the State Route 107 bridge in the Village of Bethel, Vermont, to the upstream end at about 1,000 feet upstream from the River Brook Drive bridge in the Village of Rochester, Vt., and a 7.9-mile reach of the Tweed River from its mouth in Stockbridge, Vt., to the confluence of the West and South Branches of the Tweed River and continuing upstream on the South Branch Tweed River to the Pittsfield, Vt., town line.

This report presents water-surface elevations determined for the study reaches using the U.S. Army Corps of Engineers one-dimensional step-backwater Hydrologic Engineering Center River Analysis System model, also known as HECRAS. The water-surface elevations were determined for floods having a 10-, 4-, 2-, 1-, and 0.2-percent annual exceedance probability (AEP) and for the floodway.

Eighteen high-water marks from Tropical Storm Irene were available along the studied reaches. The discharges in the Tropical Storm Irene HEC-RAS model were adjusted so that the resulting water-surface elevations matched the high-water mark elevations along the study reaches. This allowed for an estimation of the water-surface profile throughout the study area resulting from Tropical Storm Irene. From a comparison of the estimated water-surface profile of Tropical Storm Irene to the water-surface profiles of the 1- and 0.2-percent AEP floods, it was determined that the high-water elevations resulting from Tropical Storm Irene exceeded the estimated 1-percent AEP flood throughout the White River and Tweed River study reaches and exceeded the estimated 0.2-percent AEP flood in 16.7 of the 28.6 study reach miles. The simulated water-surface profiles were then combined with a geographic information system digital elevation model derived from light detection and ranging (lidar) data having a 18.2-centimeter vertical accuracy at the 95-percent confidence level and 1-meter horizontal resolution to delineate the area flooded for each water-surface profile.

\section{Introduction}

During August 28-29, 2011, record-breaking rainfall from Tropical Storm Irene resulted in extensive flooding across much of Vermont. In the White River and Tweed River valleys, the flooding resulted in extensive property damage and destruction of transportation corridors. At the White River at West Hartford, Vt., U.S. Geological (USGS) streamgage $01144000,{ }^{1}$ the discharge reached 90,100 cubic feet per second $\left(\mathrm{ft}^{3} / \mathrm{s}\right)$ - the second largest discharge ever recorded at the streamgage in its 96 years of data collection. The discharge at the streamgage was determined to have an annual exceedance probability (AEP) of 1 to 0.2 percent (Olson and Bent, 2013).

In response to the flooding, President Obama made a presidential declaration of a major disaster (Federal Emergency Management Agency [FEMA]-4022-DR) for the State of Vermont under the Robert T. Stafford Disaster Relief and Emergency Assistance Act (Stafford Act; 42 U.S.C. $\S \S 5121-5207)$. As an element of addressing the disaster declaration, the USGS, in cooperation with FEMA, has produced a series of flood recovery maps. These maps show the areal extent of flooding from Tropical Storm Irene, as well as estimated flood boundaries, resulting from floods with 10-, 4-, 2-, 1-, and 0.2-percent AEP, and the floodway. The maps cover selected reaches of the White River and the Tweed River. The reaches were selected because of the significant flood damage that occurred and the availability of digital elevation models developed from lidar data. These recovery maps (appendix 1) are for advisory purposes and do not supersede the effective Flood Insurance Rate Maps (FIRMs) (Federal Emergency Management Agency, 2007, 2008).

${ }^{1}$ The White River at West Hartford, Vermont, streamgage is outside the study area and not displayed in figure 1 or appendix 1 . 


\section{Purpose and Scope}

This report describes the development of a series of estimated flood recovery maps for the White River at Bethel, Stockbridge, and Rochester, Vt., and the Tweed River at Stockbridge and Pittsfield,Vt. (fig. 1). The study reaches include a 20.7-mile (mi) reach of the White River from the downstream end at about 2,000 feet (ft) downstream from the State Route 107 Bridge $^{2}$ in the Village of Bethel, Vt., to the upstream end at about 1,000 ft upstream from the River Brook Drive bridge in the Village of Rochester,Vt., and a 7.9-mi reach of the Tweed River from its mouth in Stockbridge, Vt., to the confluence of the West and South Branches of the Tweed River and continuing upstream on the South Branch Tweed River to the Pittsfield, Vt., town line. The Tweed River study reach includes the Tweed River and South Branch Tweed River. The flood recovery maps show the effects from the flood of Tropical Storm Irene, as well as flood boundaries resulting from floods with 10-, 4-, 2-, 1-, or 0.2-percent AEP, and the floodway. The purpose of the maps is to provide local government and citizens with the best and most up-to-date information on flood hazards to aid in the rebuilding process.

\section{Study Area Description}

The White River and its tributary, the Tweed River, are in the Green Mountains of central Vermont. The drainage basins of both rivers are primarily forested, whereas the valleys often have agricultural and residential uses. Stockbridge, Vt., the location of the confluence of the two rivers, receives 46 inches of rain annually and has a mean annual high temperature of 54 degrees Fahrenheit $\left({ }^{\circ} \mathrm{F}\right)$ and a mean annual low temperature of $31^{\circ} \mathrm{F}$ (PRISM Group, 2012a, b, c).

Both rivers drain steep upland areas of relatively high elevations. The drainage area at the downstream end of the White River study reach is 408 square miles $\left(\mathrm{mi}^{2}\right)$. The basin has a mean elevation of $1,630 \mathrm{ft}$ above the North American Vertical Datum of 1988 (NAVD 88); 78.7 percent of the basin is above $1,200 \mathrm{ft}$. The elevation of the river at the downstream end of the study reach is $510 \mathrm{ft}$, whereas many of the peaks and ridges along the western drainage divide exceed 3,000 ft. The drainage area at the downstream end the Tweed River study reach is $51.0 \mathrm{mi}^{2}$. The basin has a mean elevation of $1,830 \mathrm{ft}$ NAVD $88 ; 88.5$ percent of the basin is above $1,200 \mathrm{ft}$. The elevation at the downstream end of the study reach is $720 \mathrm{ft}$, whereas the headwaters of the basin exceed 3,000 ft in numerous locations.

The length of the White River study reach is 20.7 miles. The channel changes $312 \mathrm{ft}$ in elevation over its course and has an average slope of 15 feet per mile (ft/mi). The downstream end of the reach is $2,000 \mathrm{ft}$ downstream from the State Route 107 Bridge in the Village of Bethel, Vt., and the

\footnotetext{
${ }^{2}$ The State Route 107 bridge and other features and locations not shown in figure 1 can be found in appendix 1 .
}

reach extends upstream through Stockbridge to about $1,000 \mathrm{ft}$ upstream from the River Brook Drive bridge in the Village of Rochester, Vt. Within the study reach, the river is traversed by 3 state highway bridges, 5 local road bridges, and a concrete weir that was once used by the USGS to measure river discharge. Much of the White River study reach upstream from the confluence with the Tweed River has broad floodplains that serve agricultural purposes. Downstream from the confluence with the Tweed River, the White River has a much more incised channel with narrow or no floodplains until it enters the Town of Bethel and the floodplains once again broaden.

The length of the Tweed River study reach is $7.9 \mathrm{mi}$. The channel changes $383 \mathrm{ft}$ in elevation over its course and has an average slope of about $49 \mathrm{ft} / \mathrm{mi}$. The study reach extends from the Tweed River mouth, where the river drains into the White River, to the confluence of the West and South Branches of the Tweed River and continues upstream on the South Branch Tweed River to the Leigh Kelly Drive bridge in Pittsfield, Vt. Within the study reach, the river is traversed by 2 state highway bridges, 8 local road bridges, 2 private bridges, and 1 snowmobile trail bridge. The Tweed River has broad floodplains up to the confluence of the West and South Branches of the Tweed. As the study reach continues up the South Branch, the channel gradually steepens and the floodplains narrow until no floodplain exists and the river becomes a mountain stream.

\section{Previous Studies}

The Flood Insurance Study (FIS) for Windsor County, Vt. (FEMA, 2007), covers Bethel, Stockbridge, and Rochester, Vt. It is the effective FIS for those towns. The Windsor County FIS is a compilation of town FIS reports. The Bethel and Rochester, Vt., effective FISs were completed by the U.S. Army Corps of Engineers in 1990; Dufresne-Henry, Inc., completed the Stockbridge, Vt., FIS in 1985. The FIS for Rutland County, Vt. (FEMA, 2008), covers Pittsfield, Vt., and is the effective FIS for that town. The effective study for Pittsfield was completed by the U.S. Soil Conservation Service in 1991.

New hydrologic estimates were made and new hydraulic models were developed for this investigation. The results of this study are provided in this report and the flood recovery maps are for advisory purposes for the towns. The results and maps do not supersede the effective FISs or the FIRMs.

\section{Creation of Flood Recovery Maps}

Tasks specific to development of the flood recovery maps for the White River and Tweed River study reaches were (1) estimation of flood discharges at the 10-, 4-, 2-, 1-, and 0.2-percent AEPs, (2) collection of topographic and bathymetric data on cross sections and geometric data on structures and bridges along the study reaches, 


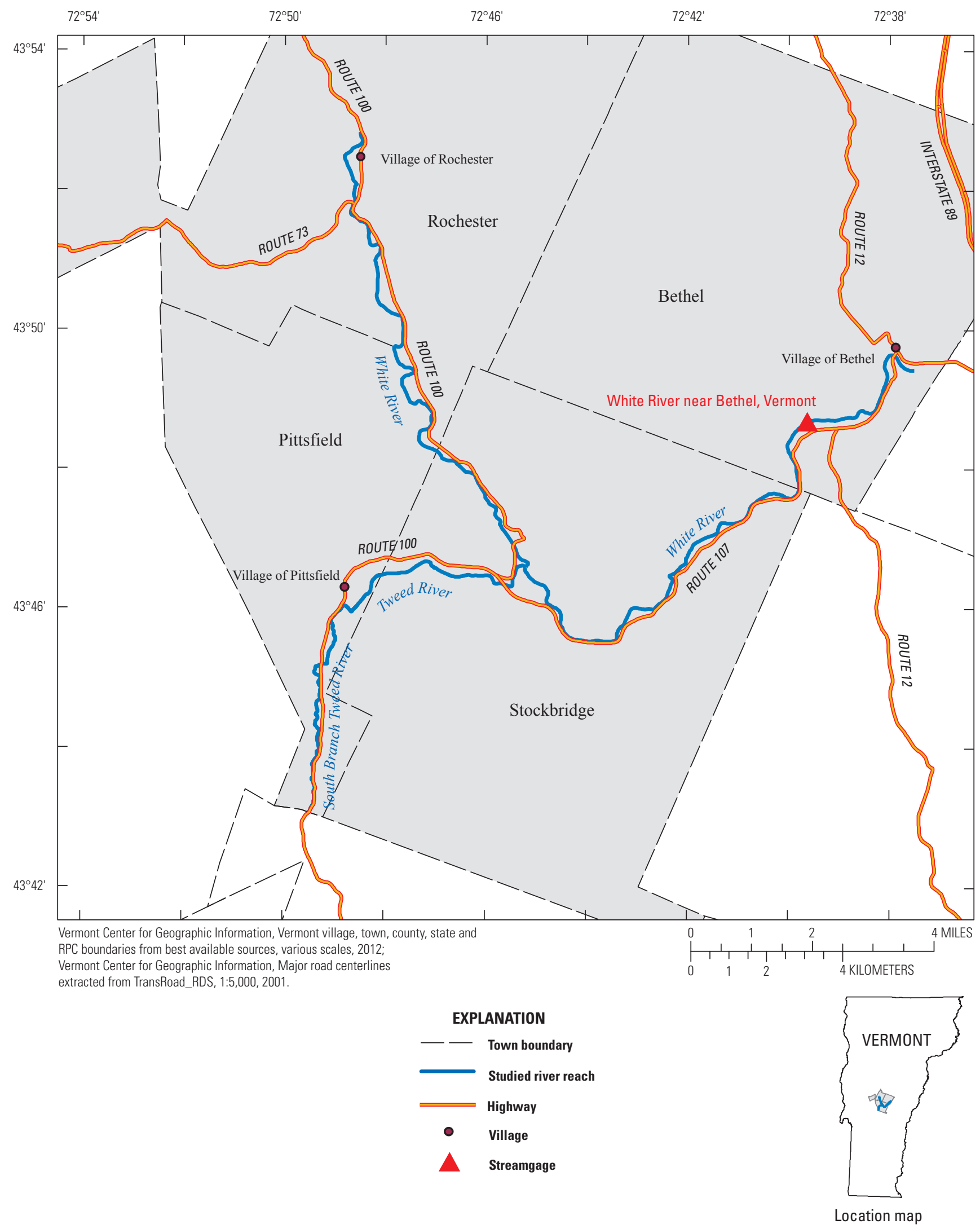

Figure 1. Location of the White and Tweed River study reaches in Bethel, Stockbridge, Pittsfield, and Rochester, Vermont. 
(3) development of the hydraulic model for the study reaches and computation of the water-surface profiles for the flood discharges using the U.S. Army Corps of Engineers HECRAS computer program (U.S. Army Corps of Engineers, 2010), and (4) production of estimated flood recovery maps at the simulated water-surface profiles using the U.S. Army Corps of Engineers HEC-GeoRAS computer program (U.S. Army Corps of Engineers, 2012) and a geographic information system (GIS).

\section{Estimation of Flood Discharges}

Flood discharges at the 10-, 4-, 2-, 1-, and 0.2-percent AEPs were estimated for the White and Tweed Rivers study reaches for use in the HEC-RAS hydraulic model. On the White River, there are two streamgages where discharge has been measured. The first streamgage, 01144000, White River at West Hartford, Vt., is an active, continuously recording USGS streamgage, but it is downstream from the study reach. Streamgage 01144000 has a drainage area of $689 \mathrm{mi}^{2}$. The second streamgage, 01142000, White River near Bethel, Vt., is within the White River study reach, but it was discontinued in 1955. It has a drainage area of $240 \mathrm{mi}^{2}$. Recent flood frequency analyses were done for both streamgages by Olson (2014).

Weighting the at-site frequency curves with the results of regression equations, as explained in Olson
(2014), lowered the discharges in frequency curves at both streamgages. Because weighting with the regression equations provided lower discharge results for the White River at both streamgages, it was decided that the additional regional information provided by the regression equations was not a good solution for these streamgages. Therefore, the at-site frequency curves were used unweighted. The discharges at each of the streamgages were interpolated and extrapolated using a constant linear relation of drainage area to discharge in logarithmic units. The relation took the form $\left(A_{1} / A_{2}\right)^{x}=$ $\left(Q_{1} / Q_{2}\right)$, where $A_{1}$ and $A_{2}$ are the drainage areas of river locations 1 and 2, $Q_{1}$ and $Q_{2}$ are the flood discharges for a selected AEP at river locations 1 and 2, and $x$ was found by solving the above equation with data from the two White River streamgages. The results are as shown in table 1.

The flood discharge for Tropical Storm Irene was $90,100 \mathrm{ft}^{3} / \mathrm{s}$ at streamgage 01144000 , White River at West Hartford, Vt. (Olson and Bent, 2013). Using a trial-and-error technique, it was found that an exponent $x$ equal to 0.510 , along with the values for discharge and drainage area of the streamgage, applied to the equation above resulted in discharges that gave water-surface elevations from the hydraulic model that matched the Tropical Storm Irene high-water marks (Medalie and Olson, 2013). These discharges, which were used to simulate the flooding from Tropical Storm Irene, are shown in table 1 .

No streamgage data were available for the Tweed River study reach. Extrapolating the White River discharges to

Table 1. Flood discharges used in the hydraulic model for the White River in West Hartford, Bethel, Stockbridge, and Rochester, Vermont.

$\left[\mathrm{mi}^{2}\right.$, square miles; $\mathrm{ft}^{3} / \mathrm{s}$, cubic feet per second; VT, Vermont]

\begin{tabular}{|c|c|c|c|c|c|c|c|}
\hline \multirow[t]{2}{*}{ Location on White River } & \multirow{2}{*}{$\begin{array}{l}\text { Drainage } \\
\text { area } \\
\left(\mathrm{mi}^{2}\right)\end{array}$} & \multicolumn{5}{|c|}{$\begin{array}{l}\text { Flood discharges }\left(\mathrm{ft}^{3} / \mathrm{s}\right) \text { for indicated } \\
\text { annual exceedance probabilities } \\
\text { (in percent) }\end{array}$} & \multirow{2}{*}{$\begin{array}{c}\text { Tropical } \\
\text { Storm Irene } \\
\text { discharge } \\
\left(\mathrm{ft}^{3} / \mathbf{s}\right)\end{array}$} \\
\hline & & 10 & 4 & 2 & 1 & 0.2 & \\
\hline$x$ in $\left(A_{1} / A_{2}\right)^{x}=\left(Q_{1} / Q_{2}\right)$ & & 0.534 & 0.550 & 0.561 & 0.577 & 0.615 & 0.510 \\
\hline $\begin{array}{l}\text { 1,000 feet upstream of River Brook Drive, } \\
\text { Rochester, VT }\end{array}$ & 71.4 & 10,300 & 13,200 & 15,800 & 18,300 & 25,300 & 28,400 \\
\hline Upstream of Breakneck Brook & 130 & 14,200 & 18,400 & 22,000 & 25,900 & 36,500 & 38,500 \\
\hline Upstream of Tweed River & 143 & 14,900 & 19,400 & 23,300 & 27,400 & 38,800 & 40,400 \\
\hline Upstream of Stony Brook & 199 & 17,800 & 23,300 & 28,000 & 33,100 & 47,500 & 47,800 \\
\hline Upstream of Lilliesville Brook & 228 & 19,200 & 25,100 & 30,200 & 35,800 & 51,600 & 51,300 \\
\hline $\begin{array}{l}\text { At streamgage 01142000, White River near } \\
\text { Bethel, VT }\end{array}$ & 240 & 19,700 & 25,800 & 31,100 & 36,900 & 53,300 & 52,600 \\
\hline $\begin{array}{l}\text { At streamgage } 01144000 \text {, White River at } \\
\text { West Hartford, VT }\end{array}$ & 689 & 34,600 & 46,100 & 56,200 & 67,800 & 102,000 & 90,100 \\
\hline
\end{tabular}


the drainage areas of the Tweed River resulted in discharges that were unreasonably large. Therefore, flood discharges for selected annual exceedence probabilities were determined using regression equations developed for rural, unregulated streams in Vermont (Olson, 2014). The resulting discharges are shown in table 2.

No discharge data were available for the Tweed River during Tropical Storm Irene. The discharges for Tropical Storm Irene were estimated by adjusting discharges in the hydraulic model so that the resulting water surface best fit the high-water marks. The discharges closely fit the log-linear drainage area relation $\left(A_{1} / A_{2}\right)^{x}=\left(Q_{1} / Q_{2}\right)$ with an $x$ of 1.10 . The resulting discharges were determined using this equation for six locations and are shown in table 2.

\section{Topographic and Bathymetric Data}

All elevation data used in this study are referenced to NAVD 88; all horizontal data are referenced to the North American Datum of 1983. Cross-section elevation data were obtained from a digital elevation model (DEM) that was derived from lidar data collected during April 2012 by Fugro Earthdata, Inc., of Frederick and Hagerstown, Maryland (Fugro EarthData, Inc., 2012a). The lidar data have a horizontal 18.2 -centimeter $(0.60-\mathrm{ft})$ vertical accuracy at the 95 -percent confidence level and 1-meter (3.28-ft) horizontal resolution.

The lidar data were collected by Fugro Earthdata, Inc., for the Vermont Agency of Transportation; the lidar data were collected along state highways that were heavily damaged following Tropical Storm Irene. The data were collected in a 1,000-meter-wide corridor that was centered on the highways. A state highway runs along most the study reaches of the
White and Tweed Rivers. In two locations, the state highway and the river diverge, and the lidar data do not cover the entire river valley. The first location is an 1,800 -ft reach on the Tweed River from 2,410 to 4,210 ft downstream from the confluence of the West and South Branches of the Tweed River. This reach includes cross sections TY, TZ, and TAA as shown in appendix 1 . The second location is a $1,485-\mathrm{ft}$ reach on the White River from 1,180 to 2,665 ft downstream from the confluence of the Tweed and White Rivers. This reach includes cross sections WBI and WBJ. In these two reaches, the best available mapping was used for out-of-channel cross-section geometry and delineation of the flood boundaries, which was the 10-meter DEM (USGS, 2004).

Using HEC-GeoRAS - a set of procedures, tools, and utilities for processing geospatial data in ArcGIS-elevation data were extracted from the DEM for 233 cross sections. Because lidar data cannot provide ground elevations below the water surface of a stream, the channel segments of the cross sections were surveyed by USGS field crews from the New England Water Science Center during spring and summer 2013. The cross-sectional bathymetry data were collected by wading or sounding at 202 sections. For these sections, withinchannel data were directly merged with the DEM data. For the other cross sections, the DEM data represented the withinchannel elevations well because the channel was a steep, pool and riffle type channel.

A differential global positioning system (DGPS) with real-time kinematic (RTK) technology was used to derive horizontal locations and elevations at the surveyed cross sections. Nine determinations of elevations by RTK DGPS at benchmark locations were within $0.06 \mathrm{ft}$ of the known elevations, an error range that exceeds the accuracy of the lidar data.

Table 2. Flood discharges used in the hydraulic model for the Tweed River and South Branch Tweed River in Stockbridge and Pittsfield, Vermont.

$\left[\mathrm{mi}^{2}\right.$, square miles; $\mathrm{ft}^{3} / \mathrm{s}$, cubic feet per second]

\begin{tabular}{|c|c|c|c|c|c|c|c|}
\hline \multirow[t]{2}{*}{ Location on river } & \multirow{2}{*}{$\begin{array}{l}\text { Drainage } \\
\text { area } \\
\left(\mathrm{mi}^{2}\right)\end{array}$} & \multicolumn{5}{|c|}{$\begin{array}{l}\text { Flood discharges (ft }{ }^{3} / \mathrm{s} \text { ) for indicated } \\
\text { annual exceedance probabilities } \\
\text { (in percent) }\end{array}$} & \multirow{2}{*}{$\begin{array}{c}\text { Tropical Storm } \\
\text { Irene discharge } \\
\left(\mathrm{ft}^{3} / \mathbf{s}\right)\end{array}$} \\
\hline & & 10 & 4 & 2 & 1 & 0.2 & \\
\hline \multicolumn{8}{|c|}{ South Branch Tweed River } \\
\hline Upstream of Johnson Brook & 9.57 & 936 & 1,250 & 1,520 & 1,820 & 2,650 & 2,130 \\
\hline \multicolumn{8}{|c|}{ Tweed River } \\
\hline Upstream of Guernsey Brook & 41.1 & 3,780 & 5,000 & 6,050 & 7,190 & 10,400 & 10,600 \\
\hline Upstream of Bartlett Brook & 48.1 & 4,300 & 5,680 & 6,860 & 8,140 & 11,700 & 12,600 \\
\hline At mouth & 51.0 & 4,500 & 5,930 & 7,160 & 8,490 & 12,200 & 13,400 \\
\hline
\end{tabular}


Flood Recovery Maps for the White River and Tweed River, Vermont, 2014

\section{Geometry of Riverine Structures}

Twenty-two riverine structures, consisting of 21 road crossings and a streamgage weir, have the potential to affect water-surface elevations during floods along the stream. Bridge and other riverine structure geometry data were obtained from field surveys conducted by personnel from the USGS New England Water Science Center during the spring and summer 2013.

There are a few exceptions to the use of the field survey data for the structures in the hydraulic model. Although the flood recovery maps represent conditions at the time of the survey, several bridges were damaged during the flooding, and some were replaced. At the time of the survey for this study, three bridges on the White River - the Route 107 bridge in the Village of Bethel, and the Route 73 and River Brook Drive bridges in Rochester-had been replaced. On the Tweed River study reach, four bridges had been repaired or replaced-a private covered bridge, the Route 100 bridge, the Stonewood Crossing bridge, and a private road bridge, all in Pittsfield. To best simulate the flooding that occurred during Tropical Storm Irene, it would be ideal to have the geometry of all the bridges that were in place during the flooding. Unfortunately, preflood data were not available for 5 of these 7 structures. The only structure data available were for the Route 107 crossing of the White River in the Village of Bethel and the Route 73 crossing of the White River in Rochester. The Route 107 bridge geometry data were taken from the hydraulic model of the effective Flood Insurance Study model for Bethel (Federal Emergency Management Agency, 2007). The geometry data for the Route 73 bridge in Rochester were provided by the Vermont Agency of Transportation (Nick Wark, written commun., September 11, 2013). The other five structures were included in the Tropical Storm Irene model as surveyed during summer 2013.

Because reconstruction continues in Vermont since Tropical Storm Irene, there are two temporary bridges included in the hydraulic model for the flood recovery maps. They are the Route 73 crossing of the White River in Rochester and the Route 100 crossing of the Tweed River in Pittsfield. In an effort to provide the most up-to-date data for the maps, the Vermont Agency of Transportation provided the geometry data for the planned Route 73 bridge in Rochester (Nick Wark, written commun., September 11, 2013). An additional model that included this planned Route 73 bridge was developed, and the data are included with the flood recovery map.

\section{Development of the Hydraulic Model}

As stated in section "Topographic and Bathymetric Data," HEC-GeoRAS - a set of procedures, tools, and utilities for processing geospatial data in ArcGIS - elevation data were extracted from the DEM for 233 cross sections. The crosssection data were merged with the surveyed channel data and subsequently were input to the HEC-RAS model. Objects blocking the flow of water, such as buildings, were digitized in a GIS and were converted to HEC-RAS input by the HECGeoRAS software. The data for the 22 riverine structures, consisting of 21 road crossings and a streamgage weir, were manually input into the HEC-RAS model.

Hydraulic analyses require the estimation of energy losses that result from frictional resistance exerted by a channel on flow. These energy losses are quantified by the Manning's roughness coefficient ( $n$-value). Initial $n$-values were selected on the basis of field observations, field photographs, and high-resolution aerial photographs (Fugro EarthData, Inc., 2012b). The initial $n$-values were adjusted to minimize the differences between simulated and observed water-surface elevations at the Tropical Storm Irene highwater marks. The $n$-values were also adjusted to avert defaults to critical depth by the HEC-RAS model. For the White River study reach, the final channel $n$-values ranged from 0.040 in straight, lower gradient, sand and gravel channels to 0.065 in meandering, steep, cobble to boulder channels. The floodplains had $n$-values ranging from 0.035 on smooth lawns to 0.085 in heavily forested areas. For the Tweed River study reach, the final $n$-values ranged from 0.040 in straight, lower gradient, sand and gravel channels to 0.075 in meandering, steep, boulder channels. The floodplain areas had $n$-values ranging from 0.040 in grassy areas to 0.110 in heavy forest with thick underbrush.

The HEC-RAS analysis for this study was done using the steady-state flow computation option. Subcritical flow regime was assumed for the simulations. Normal depth was used as the starting water surface and was based on an estimated average water-surface slope of 0.00120 for the White River and 0.00394 for the Tweed River from data contained in the effective Flood Insurance Study (Federal Emergency Management Agency, 2007) and from channel survey data. The discharges used in the model were discussed in the section, "Estimation of Flood Discharges."

The water-surface profiles for the 10-, 4-, 2-, 1-, and 0.2-percent AEP and for Tropical Storm Irene used to produce the flood recovery maps in this study were computed by using HEC-RAS, version 4.1.0 (U.S. Army Corps of Engineers, 2010). HEC-RAS is a one-dimensional step-backwater model for simulation of water-surface profiles with steadystate (gradually varied) or unsteady-state flow computation options. Differences between surveyed and simulated elevations of high-water marks for Tropical Storm Irene are shown in table 3. Many of the differences exceed 1 foot. However, these differences are for sites near bridges that were replaced following the flood, for sites in reaches with debris issues, or for sites in steep reaches where the high-water mark may be more representative of the energy grade line than the water surface. Two of the high-water marks that have elevations more than $4 \mathrm{ft}$ less than the simulated water surface are likely to be erroneously flagged marks, and little confidence was placed in these marks in the model adjustment process. The results demonstrate that the model is capable of simulating 
Table 3. Comparison of simulated water-surface elevations to observed high-water marks at selected locations along the White and Tweed River study reaches for Tropical Storm Irene, August 27-28, 2011.

[ft, feet; NAVD 88, North American Vertical Datum of 1988]

\begin{tabular}{cccc}
\hline $\begin{array}{c}\text { River station } \\
\text { (ft) }\end{array}$ & $\begin{array}{c}\text { Surveyed water-surface } \\
\text { elevation } \\
\text { (ft, NAVD 88) }\end{array}$ & $\begin{array}{c}\text { Simulated water-surface } \\
\text { elevation } \\
\text { (ft, NAVD 88) }\end{array}$ & $\begin{array}{c}\text { Difference in elevations } \\
\text { (ft) }\end{array}$ \\
\hline \multicolumn{3}{c}{ White River } \\
\hline 2,150 & 536.95 & 541.67 & 4.72 \\
2,439 & 545.67 & 543.33 & -2.34 \\
3,052 & 546.33 & 545.31 & -1.02 \\
13,174 & 560.19 & 560.22 & 0.03 \\
90,648 & 792.41 & 792.80 & 0.39 \\
99,467 & 822.77 & 822.49 & -0.28 \\
108,097 & 835.02 & 835.06 & 0.04 \\
108,215 & 837.05 & 835.41 & -1.64 \\
\hline & & & -0.18 \\
3,219 & 745.55 & 745.37 & -0.45 \\
5,667 & 753.23 & 752.78 & 0.55 \\
5,906 & 756.17 & 756.72 & -0.53 \\
20,618 & 839.15 & 838.62 & -1.94 \\
20,754 & 842.80 & 840.86 & 5.62 \\
22,253 & 847.06 & 852.68 & -0.62 \\
26,919 & 891.03 & 890.41 & -0.34 \\
30,110 & 932.03 & 931.69 & 0.94 \\
38,016 & $1,040.21$ & $1,041.15$ & 0.01 \\
38,742 & $1,054.86$ & $1,054.87$ & \\
\hline
\end{tabular}

${ }^{1}$ River station is referenced to the longitudinal baseline used in the hydraulic model and is measured in feet from the downstream end of the model.

accurate water levels. The resulting water-surface elevations for the 10-, 4-, 2-, 1-, and 0.2-percent AEP and Tropical Storm Irene are in appendix 2. Water-surface elevations determined using the hydraulic model with the new Route 73 bridge are in appendix 3.

A floodway was also determined for the study reaches. A floodway is the channel plus adjacent floodplain areas that must be free of intrusions, such as fill or development, so that the 1-percent AEP flood can be carried without substantial increases in water-surface elevations. The increase allowed in the analysis is 1.00 foot. The floodway was computed by using HEC-RAS, version 4.1.0 (U.S. Army Corps of Engineers, 2010). The results of the floodway analysis, by cross section, are in appendix 4. Results of the floodway analysis modified for the planned new Route 73 bridge are in appendix 5 .

\section{Annual Exceedance Probability of Flooding From Tropical Storm Irene}

A 20.7-mile reach of the White River was included in this investigation. On the basis of the hydraulic models, Tropical Storm Irene discharge exceeded the 1-percent AEP flood throughout the White River study reach and exceeded the 0.2-percent AEP flood in the upper 12.6 miles of the White River study reach. A 7.9-mile reach of the Tweed River was included in this investigation. Tropical Storm Irene discharge exceeded the 1-percent AEP flood throughout the Tweed River study reach and exceeded the 0.2-percent AEP flood in the lower 4.2 miles of the Tweed River study reach, including the entire reach below the confluence of the South and West Branches of the Tweed River. 


\section{Development of Flood Recovery Maps}

Flood recovery maps were created in a GIS by combining the water-surface profiles and the DEM data. The DEM data were derived from the same lidar data described in section "Topographic and Bathymetric Data and Geometry of Riverine Structures." Estimated flood-inundation boundaries for each simulated profile were developed with HEC-GeoRAS software (U.S. Army Corps of Engineers, 2012), which allows the preparation of geometric data for import into HEC-RAS and processes simulation results exported from HEC-RAS (U.S. Army Corps of Engineers, 2010). Shapefile polygons of the inundated areas for each profile were modified, as required, in the ArcMap application of ArcGIS (Environmental Systems Research Institue, Inc., 2012a) to ensure a hydraulically reasonable transition of the flood boundaries between modeled cross sections.

Any inundated areas that were detached from the main channel were examined to identify subsurface connections with the main river, such as through culverts under roadways. Where such connections existed, the mapped inundated areas were retained in their respective flood recovery maps; otherwise, the erroneously delineated parts of the flood extent were deleted. The flood-inundation areas were overlaid on geo-referenced aerial photographs of the study area (U.S. Department of Agriculture, 2012). A visual comparison was made between the 1-percent AEP flood boundary from the effective FIRM and the 1-percent AEP flood boundary generated in this investigation. The boundaries were comparable, but the boundaries generated in this investigation appear to have greater detail.

The Flood Recovery Mapping is provided in appendix 1. Appendix 1 contains an ArcGIS published map document (.pmf) that can be read using the freeware, ArcReader (Environmental Systems Research Institute, Inc. [ESRI], 2012b). ArcReader version 10.1 can be downloaded from ESRI at http://www.esri.com/software/arcgis/arcreader/. The published map document provides the flood boundaries for the 10-, 4-, 2-, 1-, and 0.2-percent AEP floods, the floodway, and Tropical Storm Irene. It also contains cross sections with identifiers and the base flood-elevation markers. The base flood-elevations markers indicate the elevation of the 1-percent AEP at 2-foot elevation increments along the study reaches. Flood boundaries and the floodway at the Route 73 bridge in Rochester, Vt., that correspond to the planned bridge design are also incorporated into the map document.

\section{Uncertainties and Limitations Regarding Use of Flood Recovery Maps}

Although the flood recovery maps represent the boundaries of inundated areas with a distinct line, some uncertainty is associated with these maps. The accuracy of the floodwater extent portrayed on these maps will vary with the accuracy of the DEM used to simulate the land surface. Water-surface elevations computed with the HEC-RAS model were estimated using steady-state hydraulic modeling, assuming unobstructed flow from ice or debris. The hydraulic model reflects the land-cover characteristics, roughness characteristics, channel elevations, and any bridge, dam, or other hydraulic structures existing as of August 2013. Changes to any of these features may change the water-surface profile.

Furthermore, unique meteorological factors (timing and distribution of precipitation) may cause actual streamflows along the modeled reach to vary from those assumed to occur during a flood, which may lead to deviations from the watersurface elevations and flood boundaries shown. Additional areas may be flooded due to unanticipated conditions such as changes in the streambed elevation or roughness, backwater into major tributaries along a main stem river, or backwater from localized debris or ice jams. The USGS provides these maps as a reference and emergency planning tool but assumes no legal liability or responsibility resulting from the use of this information.

\section{Summary}

A series of digital flood recovery maps for water-surface elevations for floods with a 10-, 4-, 2-, 1-, and 0.2-percent annual exceedance probability (AEP) and for the floodway were developed by the U.S. Geological Survey in cooperation with the Federal Emergency Management Agency for the White River at Bethel, Stockbridge, and Rochester, Vermont, and for the Tweed River at Stockbridge and Pittsfield, Vt. These flood recovery maps include a 20.7-mile reach of the White River from the downstream end at about 2,000 feet downstream from the State Route 107 bridge in the Village of Bethel, Vt., to the upstream end at about 1,000 feet upstream from the River Brook Drive bridge in the Village of Rochester,Vt., and a 7.9-mile reach of the Tweed River from its mouth in Stockbridge, Vt., to the confluence of the West and South Branches of the Tweed River and continuing upstream on the South Branch Tweed River to the Leigh Kelly Drive bridge in Pittsfield, Vt. The maps were developed by using the U.S. Army Corps of Engineers HEC-RAS and HEC-GeoRAS programs to compute water-surface profiles and to delineate estimated flood-inundation areas. 


\section{References Cited}

Environmental Systems Research Institute, Inc., 2012a, ArcGIS, version 10.1: Redlands, Calif., accessed June 27, 2014, at http://www.esri.com/software/arcgis/.

Environmental Systems Research Institute, Inc., 2012b, ArcGIS, ArcReader version 10.1: Redlands, Calif., accessed October 10, 2014, at http://www.esri.com/software/arcgis/ arcreader.

Federal Emergency Management Agency, 2007, Flood insurance study, Windsor County, Vermont (all jurisdictions): Washington, D.C., Federal Emergency Management Agency, $4 \mathrm{v}$.

Federal Emergency Management Agency, 2008, Flood insurance study, Rutland County, Vermont (all jurisdictions): Washington D.C., Federal Emergency Management Agency, $3 \mathrm{v}$.

Fugro EarthData, Inc., 2012a, VTrans_DEM: Montpelier, Vt., Vermont Agency of Transportation, accessed January 7, 2015, at http://vcgi.vermont.gov/warehouse/products/ ALL-LDR_MIX_LIDAR_STATE_ALL.

Fugro EarthData, Inc., 2012b, VTrans_Ortho: Montpelier, Vt., Vermont Agency of Transportation data.

Medalie, Laura, and Olson, S.A., 2013, High-water marks from flooding in Lake Champlain from April through June 2011 and Tropical Storm Irene in August 2011 in Vermont: U.S. Geological Survey Data Series 763, 11 p., accessed July 14, 2014, at http://pubs.usgs.gov/ds/763/.

Olson, S.A., 2014, Estimation of flood discharges at selected annual exceedance probabilities for unregulated, rural streams in Vermont, with a section on Vermont regional skew regression, by Veilleux, A.G.: U.S. Geological Survey Scientific Investigations Report 2014-5078, 27 p. plus appendixes, accessed July 7, 2014, at http:/dx.doi. org/10.3133/sir20145078.
Olson, S.A., and Bent, G.C., 2013, Annual exceedance probabilities of the peak discharges of 2011 at streamgages in Vermont and selected streamgages in New Hampshire, western Massachusetts, and northeastern New York: U.S. Geological Survey Scientific Investigations Report 2013-5187, 17 p., accessed July 7, 2014, at http://dx.doi.org/10.3133/sir20135187.

PRISM Group, Oregon State University, 2012a, United States average monthly or annual precipitation, 1981-2010, 30 arc-second normal, created July 10, 2012: Corvallis, Oreg., Oregon State University, accessed September 16, 2013, at http://www.prism.oregonstate.edu/.

PRISM Group, Oregon State University, 2012b, United States average monthly or annual maximum temperature, 1981-2010, 4 km grid cell resolution, created July 10, 2012: Corvallis, Oreg., Oregon State University, accessed September 16, 2013, at http://www.prism.oregonstate.edu/.

PRISM Group, Oregon State University, 2012c, United States average monthly or annual minimum temperature, 1981-2010, 4 km grid cell resolution, created July 10, 2012: Corvallis, Oreg., Oregon State University, accessed September 16, 2013, at http://www.prism.oregonstate.edu/.

U.S. Army Corps of Engineers, Hydrologic Engineering Center, 2010, HEC-RAS river analysis system, user's manual, version 4.1: U.S. Army Corps of Engineers [variously paged].

U.S. Army Corps of Engineers, Hydrologic Engineering Center, 2012, HEC-GeoRAS, GIS tools for support of HEC-RAS using ArcGIS 10, user's manual, version 10: U.S. Army Corps of Engineers [variously paged].

U.S. Department of Agriculture, 2012, National Agriculture Imagery Program, 1:40,000 scale: U.S. Department of Agriculture, accessed July 7, 2014, at http://vcgi.vermont.gov/.

U.S. Geological Survey, 2004, National elevation dataset, 1 arc-second: U.S. Geological Survey, accessed October 18, 2013, at http://ned.usgs.gov/. 



\section{Appendix 1. Flood Recovery Maps at Selected Annual Exceedance Probabilities for the White and Tweed Rivers in Bethel, Stockbridge, Pittsfield, and Rochester, Vermont}

[Available separately for download at http://pubs.usgs.gov/sir/2015/5056/.] 



\section{Appendix 2. Water-Surface Elevations for Selected Annual Exceedance Probabilites for the White River in Bethel, Stockbridge, and Rochester, Vermont, and Tweed River in Stockbridge and Pittsfield, Vermont}


Table 2-1. Water-surface elevations for selected annual exceedence probabilities for the White River in Bethel, Stockbridge, and Rochester, Vermont, and Tweed River in Stockbridge and Pittsfield, Vermont.

[Cross sections with identifiers are shown in appendix 5. ft, feet; NAVD 88, North American Vertical Datum of 1988; \%, percent; VT, Vermont]

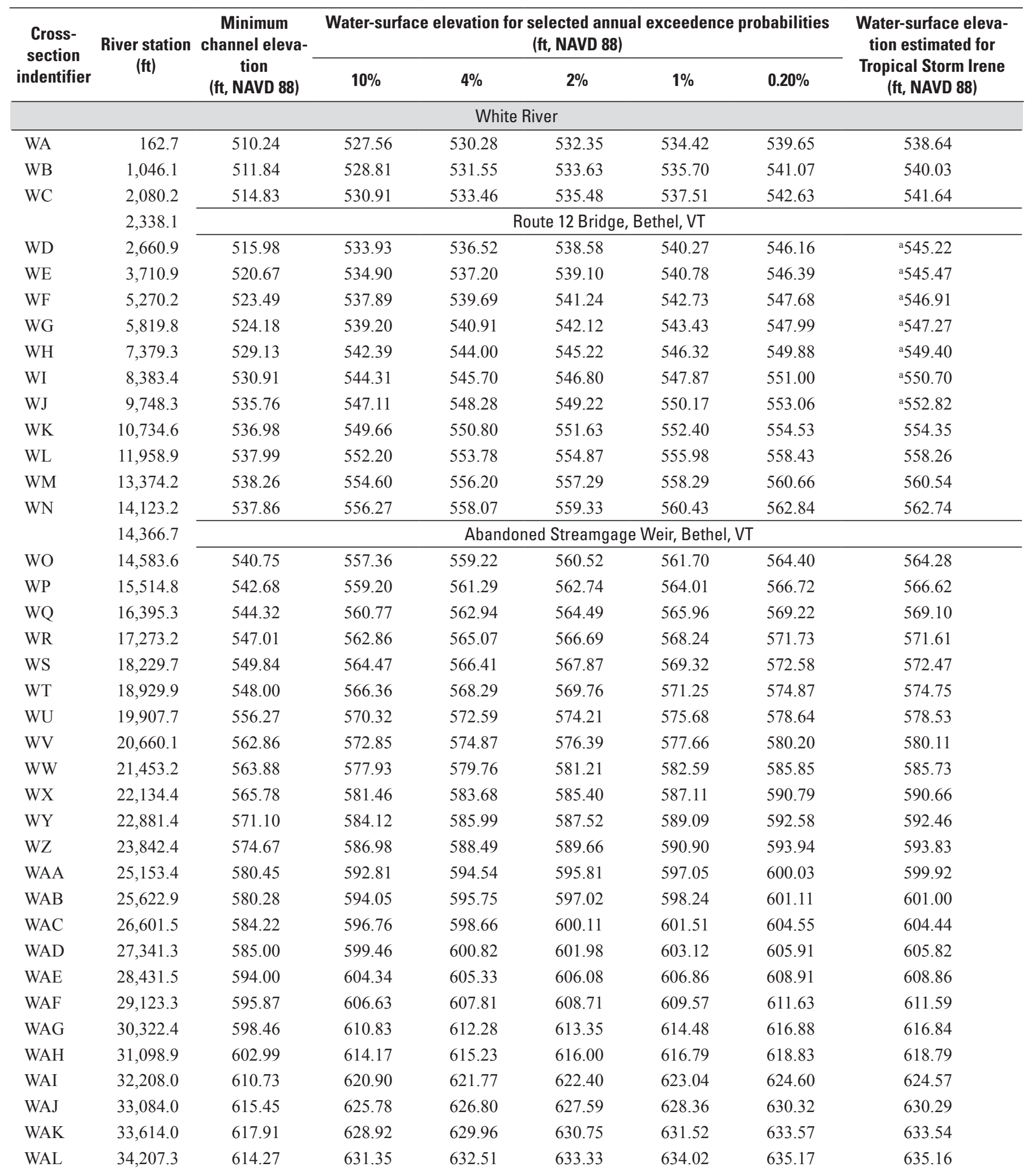


Table 2-1. Water-surface elevations for selected annual exceedence probabilities for the White River in Bethel, Stockbridge, and Rochester, Vermont, and Tweed River in Stockbridge and Pittsfield, Vermont.-Continued

[Cross sections with identifiers are shown in appendix 5. ft, feet; NAVD 88, North American Vertical Datum of 1988; \%, percent; VT, Vermont]

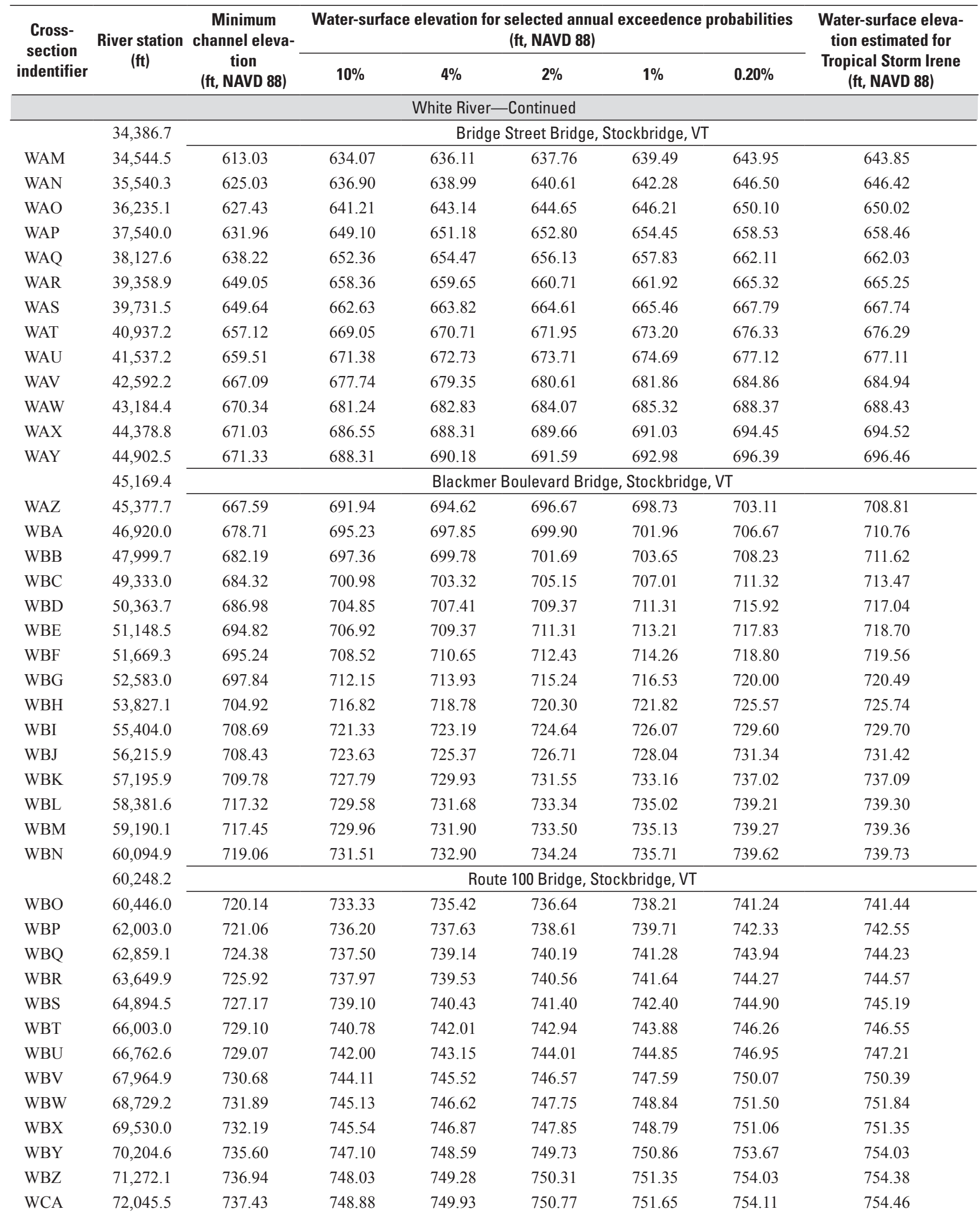


Table 2-1. Water-surface elevations for selected annual exceedence probabilities for the White River in Bethel, Stockbridge, and Rochester, Vermont, and Tweed River in Stockbridge and Pittsfield, Vermont.-Continued

[Cross sections with identifiers are shown in appendix 5. ft, feet; NAVD 88, North American Vertical Datum of 1988; \%, percent; VT, Vermont]

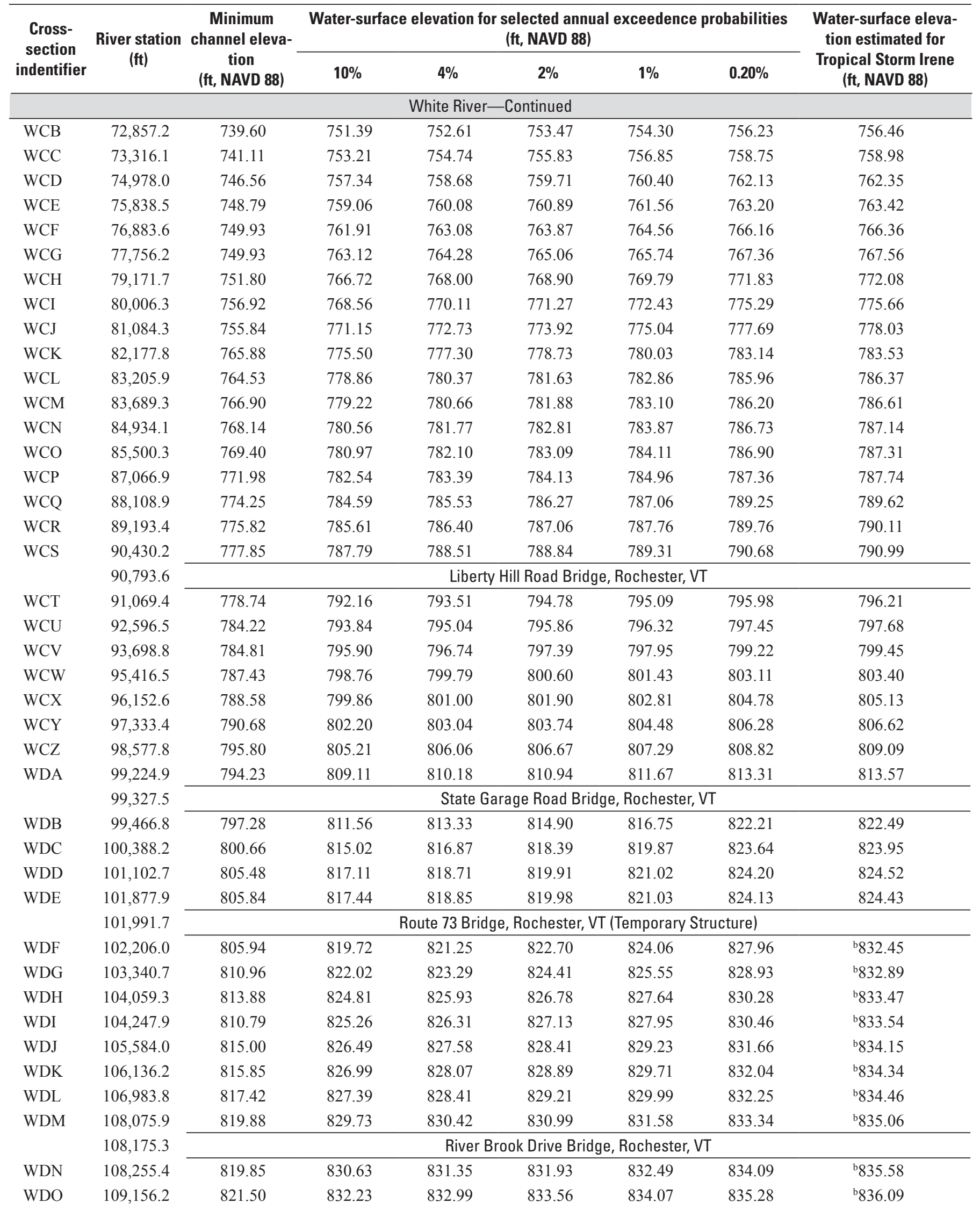


Table 2-1. Water-surface elevations for selected annual exceedence probabilities for the White River in Bethel, Stockbridge, and Rochester, Vermont, and Tweed River in Stockbridge and Pittsfield, Vermont.-Continued

[Cross sections with identifiers are shown in appendix 5. ft, feet; NAVD 88, North American Vertical Datum of 1988; \%, percent; VT, Vermont]

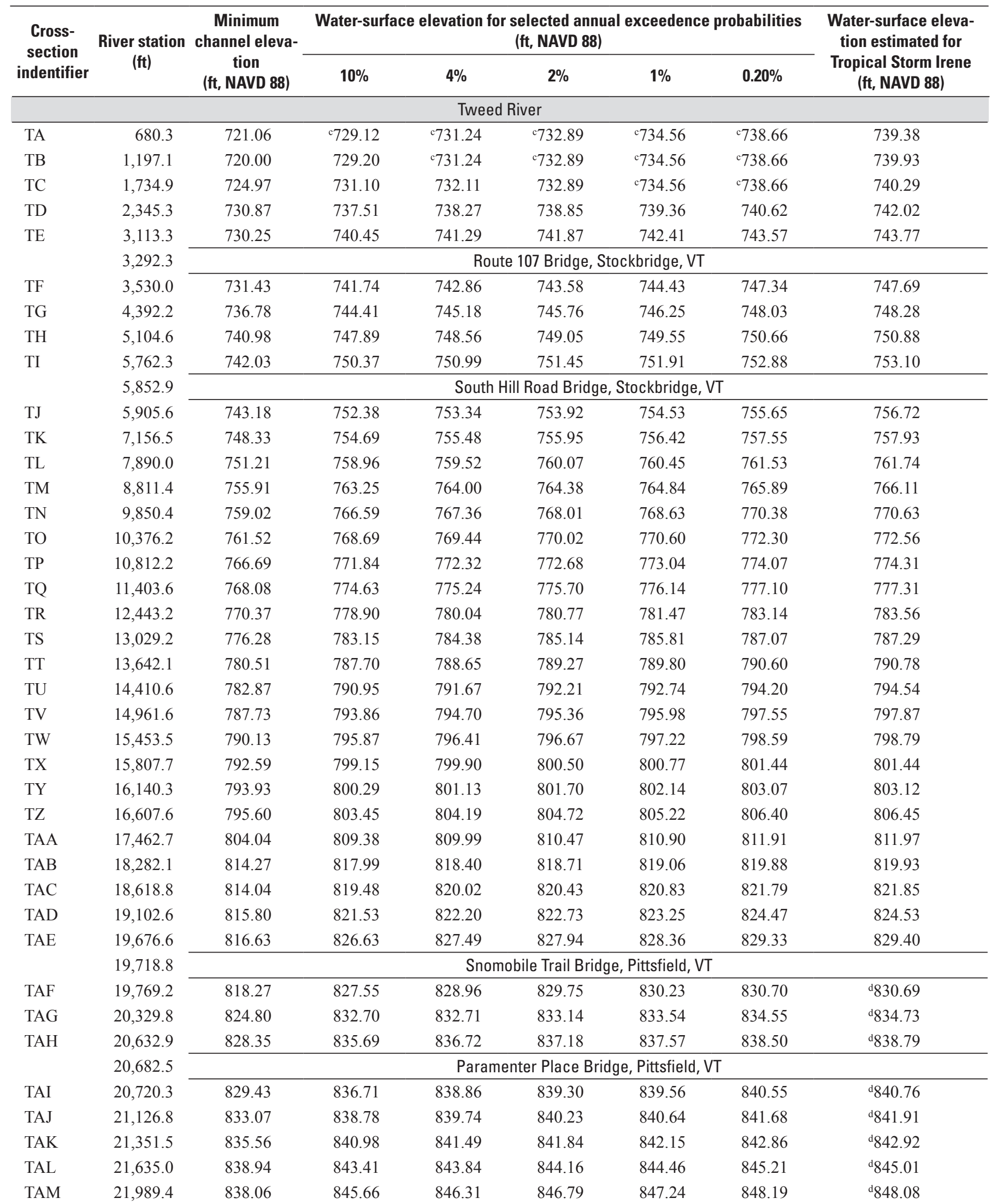


Table 2-1. Water-surface elevations for selected annual exceedence probabilities for the White River in Bethel, Stockbridge, and Rochester, Vermont, and Tweed River in Stockbridge and Pittsfield, Vermont.-Continued

[Cross sections with identifiers are shown in appendix 5. ft, feet; NAVD 88, North American Vertical Datum of 1988; \%, percent; VT, Vermont]

\begin{tabular}{|c|c|c|c|c|c|c|c|c|}
\hline \multirow{2}{*}{$\begin{array}{l}\text { Cross- } \\
\text { section } \\
\text { indentifier }\end{array}$} & \multirow{2}{*}{$\begin{array}{c}\text { River station } \\
\text { (ft) }\end{array}$} & \multirow{2}{*}{$\begin{array}{c}\text { Minimum } \\
\text { channel eleva- } \\
\text { tion } \\
\text { (ft, NAVD 88) }\end{array}$} & \multicolumn{5}{|c|}{$\begin{array}{l}\text { Water-surface elevation for selected annual exceedence probabilities } \\
\text { (ft, NAVD 88) }\end{array}$} & \multirow{2}{*}{$\begin{array}{l}\text { Water-surface eleva- } \\
\text { tion estimated for } \\
\text { Tropical Storm Irene } \\
\text { (ft, NAVD 88) }\end{array}$} \\
\hline & & & $10 \%$ & $4 \%$ & $2 \%$ & $1 \%$ & $0.20 \%$ & \\
\hline & $22,037.5$ & \multicolumn{7}{|c|}{ Covered Bridge (Private), Pittsfield, VT } \\
\hline TAN & $22,110.8$ & 837.96 & 846.72 & 847.98 & 849.09 & 851.37 & 852.65 & 852.41 \\
\hline TAO & $22,360.7$ & \multicolumn{7}{|c|}{ Tweed River Drive Bridge, Pittsfield, VT } \\
\hline TAP & $22,449.8$ & 841.67 & 848.63 & 849.59 & 850.62 & 852.34 & 853.77 & 853.52 \\
\hline TAQ & $22,964.7$ & 847.57 & 853.15 & 853.51 & 853.69 & 853.85 & 854.85 & 854.65 \\
\hline TAR & $23,478.9$ & 853.31 & 857.19 & 857.50 & 857.81 & 858.10 & 858.15 & 858.11 \\
\hline TAS & $24,387.6$ & 858.83 & 863.83 & 864.34 & 864.66 & 864.98 & 866.56 & 866.37 \\
\hline \multirow[t]{2}{*}{ TAW } & $26,680.5$ & 877.46 & 882.90 & 883.58 & 884.10 & 884.58 & 885.65 & 885.45 \\
\hline & $26,769.2$ & \multicolumn{7}{|c|}{ Route 100 Bridge, Pittsfield, VT (Temporary Structure) } \\
\hline TAX & $26,883.3$ & 880.02 & 886.06 & 887.03 & 887.78 & 888.56 & 890.55 & 890.13 \\
\hline TAY & $27,560.7$ & 889.76 & 893.01 & 893.26 & 893.67 & 894.10 & 895.18 & 894.91 \\
\hline TAZ & $28,018.4$ & 894.42 & 899.55 & 900.20 & 900.60 & 901.00 & 901.93 & 901.78 \\
\hline TBA & $28,645.7$ & 900.85 & 906.63 & 906.97 & 907.35 & 907.67 & 908.77 & 908.61 \\
\hline TBB & $29,049.6$ & 908.47 & 913.34 & 914.04 & 914.52 & 914.91 & 915.90 & 915.71 \\
\hline $\mathrm{TBC}$ & $29,466.3$ & 912.17 & 917.59 & 918.05 & 918.41 & 918.80 & 919.53 & 919.31 \\
\hline \multirow[t]{2}{*}{ TBD } & $30,030.2$ & 918.47 & 923.60 & 924.53 & 925.16 & 925.73 & 926.77 & 926.29 \\
\hline & $30,063.9$ & \multicolumn{7}{|c|}{ Bakers Road Bridge, Pittsfield, VT } \\
\hline TBK & $32,569.5$ & 948.46 & 952.38 & 952.82 & 953.16 & 953.48 & 953.72 & 953.71 \\
\hline TBL & $33,063.3$ & 955.74 & 959.43 & 959.94 & 960.32 & 960.73 & 961.35 & 960.87 \\
\hline TBM & $33,549.2$ & 962.89 & 965.71 & 966.08 & 966.38 & 966.66 & 967.77 & 967.57 \\
\hline \multirow[t]{2}{*}{$\mathrm{TBN}$} & $33,851.3$ & 965.42 & 969.86 & 970.33 & 970.67 & 971.02 & 971.82 & 971.44 \\
\hline & $33,919.7$ & \multicolumn{7}{|c|}{ Stonewood Crossing Bridge, Pittsfield, VT } \\
\hline TBO & $33,987.0$ & 967.22 & 971.61 & 972.10 & 972.50 & 972.77 & 973.52 & 973.22 \\
\hline TBP & $34,322.5$ & 971.39 & 974.84 & 975.41 & 975.80 & 976.28 & 977.11 & 976.78 \\
\hline TBQ & $34,766.2$ & 976.64 & 981.97 & 982.52 & 982.94 & 983.28 & 984.07 & 983.76 \\
\hline TBR & $35,175.3$ & 981.86 & 986.67 & 987.38 & 987.84 & 988.34 & 989.19 & 988.86 \\
\hline TBS & $35,466.7$ & 989.76 & 992.90 & 993.37 & 993.70 & 993.97 & 994.86 & 994.43 \\
\hline \multirow[t]{2}{*}{ TBT } & $35,665.3$ & 993.54 & 996.65 & 996.98 & 997.23 & 997.52 & 998.09 & 997.70 \\
\hline & $35,719.8$ & \multicolumn{7}{|c|}{ Private Drive Bridge, Pittsfield, VT } \\
\hline TBU & $35,768.7$ & 994.00 & 998.51 & 999.16 & 999.69 & 999.94 & $1,001.84$ & $1,000.43$ \\
\hline TBV & $35,985.8$ & 997.90 & $1,001.31$ & $1,001.86$ & $1,002.29$ & $1,002.67$ & $1,003.61$ & $1,003.06$ \\
\hline TBW & $36,320.7$ & $1,004.17$ & $1,008.30$ & $1,008.75$ & $1,008.97$ & $1,009.26$ & $1,009.97$ & $1,009.53$ \\
\hline
\end{tabular}


Table 2-1. Water-surface elevations for selected annual exceedence probabilities for the White River in Bethel, Stockbridge, and Rochester, Vermont, and Tweed River in Stockbridge and Pittsfield, Vermont.-Continued

[Cross sections with identifiers are shown in appendix 5. ft, feet; NAVD 88, North American Vertical Datum of 1988; \%, percent; VT, Vermont]

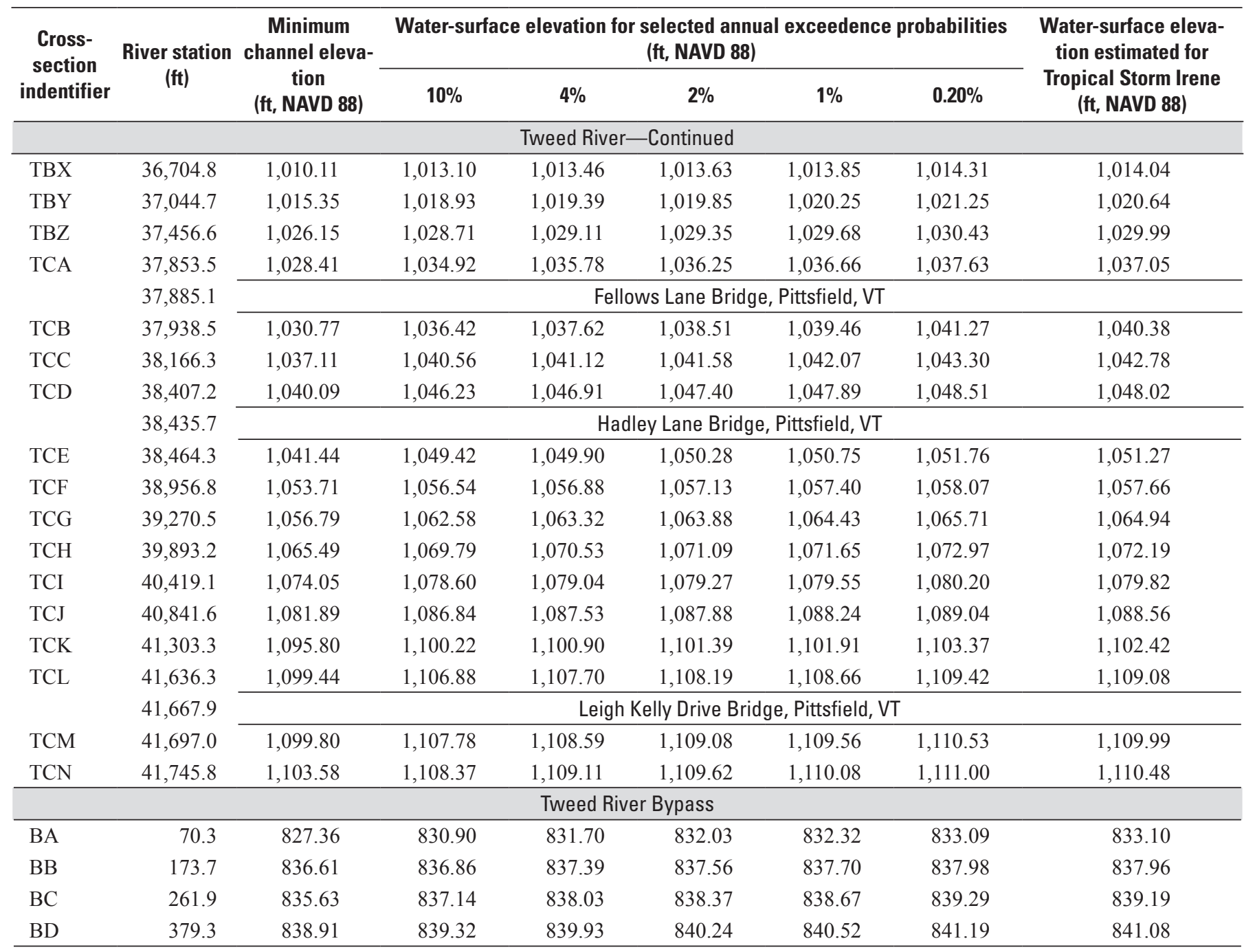

${ }^{a}$ With Route 12 bridge geometry as it existed prior to Tropical Storm Irene.

${ }^{b}$ With Route 73 bridge geometry as it existed prior to Tropical Storm Irene.

'Backwater from White River.

dPeak water-surface without bypass diversion. 

Appendix 3. Water-Surface Elevations for Selected Annual Exceedence Probabilities for the White River Modified for the Planned Route 73 Bridge in Rochester, Vermont 


\section{Flood Recovery Maps for the White River and Tweed River, Vermont, 2014}

Table 3-1. Water-surface elevations for selected annual exceedance probabilities for the White River modified for the planned Route 73 bridge in Rochester, Vermont.

[Cross sections with identifiers are shown in appendix 5. NAVD 88, North American Vertical Datum of 1988; ft, feet; VT, Vermont; --, no change in water-surface elevation resulting from planned geometry of new Route 73 bridge]

\begin{tabular}{ccccccc}
\hline \multirow{2}{*}{$\begin{array}{c}\text { Cross-section } \\
\text { indentifier }\end{array}$} & $\begin{array}{c}\text { River station } \\
\text { (ft) }\end{array}$ & $\begin{array}{c}\text { Minimum channel } \\
\text { elevation } \\
\text { (ft, NAVD 88) }\end{array}$ & \multicolumn{3}{c}{ Water-surface elevation for selected annual exceedence probabilities } \\
\cline { 4 - 7 } (ft, NAVD 88)
\end{tabular}


Appendix 4. Results of the Floodway Analysis for the White River in Bethel, Stockbridge, and Rochester, Vermont, and the Tweed River in Stockbridge and Pittsfield, Vermont 
Table 4-1. Results of the floodway analysis for the White River in Bethel, Stockbridge, and Rochester, Vermont, and the Tweed River in Stockbridge and Pittsfield, Vermont.

[Cross sections with identifiers are shown in appendix 5. ft, feet; $\mathrm{ft}^{2}$, square feet; ft/s, feet per second; NAVD 88, North American Vertical Datum of 1988]

\begin{tabular}{|c|c|c|c|c|c|c|c|}
\hline \multirow{2}{*}{$\begin{array}{l}\text { Cross-section } \\
\text { indentifier }\end{array}$} & \multirow{2}{*}{$\begin{array}{l}\text { River station - } \\
\text { (ft) }\end{array}$} & \multicolumn{3}{|c|}{ Floodway } & \multicolumn{3}{|c|}{ Water-surface elevation } \\
\hline & & $\begin{array}{l}\text { Width } \\
\text { (ft) }\end{array}$ & $\begin{array}{c}\text { Section area } \\
\left(\mathrm{ft}^{2}\right)\end{array}$ & $\begin{array}{c}\text { Mean velocity } \\
\text { (ft/s) }\end{array}$ & $\begin{array}{l}\text { Without floodway } \\
\text { (ft, NAVD 88) }\end{array}$ & $\begin{array}{l}\text { With floodway } \\
\text { (ft, NAVD 88) }\end{array}$ & $\begin{array}{c}\text { Increase } \\
\text { (ft) }\end{array}$ \\
\hline \multicolumn{8}{|c|}{ White River } \\
\hline WA & 162.7 & 286.9 & 5,665 & 8.84 & 534.42 & 534.78 & 0.36 \\
\hline WB & $1,046.1$ & 329.6 & 6,048 & 8.28 & 535.70 & 536.10 & 0.39 \\
\hline \multirow[t]{2}{*}{ WC } & $2,080.2$ & 345.5 & 5,624 & 8.91 & 537.51 & 537.86 & 0.35 \\
\hline & $2,338.1$ & \multicolumn{6}{|c|}{ Route 12 Bridge, Bethel, VT } \\
\hline WD & $2,660.9$ & 570.0 & 9,380 & 5.34 & 540.27 & 540.63 & 0.36 \\
\hline WE & $3,710.9$ & 445.0 & 6,022 & 6.58 & 540.78 & 541.44 & 0.66 \\
\hline WF & $5,270.2$ & 660.0 & 6,400 & 6.19 & 542.73 & 543.62 & 0.89 \\
\hline WG & $5,819.8$ & 620.0 & 6,246 & 6.34 & 543.43 & 544.44 & 1.00 \\
\hline WH & $7,379.3$ & 571.3 & 5,776 & 6.86 & 546.32 & 547.02 & 0.70 \\
\hline WI & $8,383.4$ & 510.0 & 5,796 & 6.83 & 547.87 & 548.40 & 0.53 \\
\hline WJ & $9,748.3$ & 930.0 & 6,975 & 5.68 & 550.17 & 551.17 & 1.00 \\
\hline WK & $10,734.6$ & 475.7 & 4,690 & 8.44 & 552.40 & 553.04 & 0.64 \\
\hline WL & $11,958.9$ & 510.0 & 5,097 & 7.24 & 555.98 & 556.22 & 0.24 \\
\hline WM & $13,374.2$ & 290.0 & 4,055 & 9.10 & 558.29 & 559.26 & 0.97 \\
\hline \multirow[t]{2}{*}{$\mathrm{WN}$} & $14,123.2$ & 215.0 & 3,655 & 10.10 & 560.43 & 561.11 & 0.68 \\
\hline & $14,366.7$ & \multicolumn{6}{|c|}{ Abandoned Streamgage Weir, Bethel, VT } \\
\hline WO & $14,583.6$ & 240.0 & 3,607 & 10.23 & 561.70 & 562.65 & 0.96 \\
\hline WP & $15,514.8$ & 196.0 & 3,740 & 9.87 & 564.01 & 564.72 & 0.71 \\
\hline WQ & $16,395.3$ & 205.0 & 3,775 & 9.77 & 565.96 & 566.62 & 0.66 \\
\hline WR & $17,273.2$ & 313.0 & 5,216 & 7.07 & 568.24 & 568.93 & 0.69 \\
\hline WS & $18,229.7$ & 231.0 & 3,677 & 10.04 & 569.32 & 570.08 & 0.76 \\
\hline WT & $18,929.9$ & 170.3 & 2,841 & 12.99 & 571.25 & 571.59 & 0.34 \\
\hline WU & $19,907.7$ & 252.0 & 4,138 & 8.92 & 575.68 & 576.35 & 0.67 \\
\hline WV & $20,660.1$ & 242.7 & 3,089 & 11.95 & 577.66 & 578.20 & 0.54 \\
\hline WW & $21,453.2$ & 197.6 & 2,705 & 13.64 & 582.59 & 582.63 & 0.04 \\
\hline WX & $22,134.4$ & 331.9 & 4,351 & 8.48 & 587.11 & 587.13 & 0.02 \\
\hline WY & $22,881.4$ & 380.2 & 5,108 & 7.22 & 589.09 & 589.49 & 0.40 \\
\hline WZ & $23,842.4$ & 231.0 & 3,104 & 11.89 & 590.90 & 591.33 & 0.44 \\
\hline WAA & $25,153.4$ & 364.7 & 4,373 & 8.44 & 597.05 & 597.41 & 0.36 \\
\hline WAB & $25,622.9$ & 253.3 & 3,623 & 10.18 & 598.24 & 598.47 & 0.23 \\
\hline WAC & $26,601.5$ & 452.0 & 4,325 & 8.28 & 601.51 & 601.68 & 0.17 \\
\hline WAD & $27,341.3$ & 540.0 & 4,599 & 7.78 & 603.12 & 603.82 & 0.70 \\
\hline WAE & $28,431.5$ & 552.1 & 5,012 & 7.14 & 606.86 & 607.85 & 0.99 \\
\hline WAF & $29,123.3$ & 277.0 & 3,364 & 10.64 & 609.57 & 609.83 & 0.26 \\
\hline WAG & $30,322.4$ & 670.0 & 5,740 & 6.24 & 614.48 & 614.77 & 0.30 \\
\hline WAH & $31,098.9$ & 685.0 & 4,465 & 8.02 & 616.79 & 617.04 & 0.25 \\
\hline WAI & $32,208.0$ & 531.3 & 4,309 & 8.31 & 623.04 & 623.99 & 0.95 \\
\hline WAJ & $33,084.0$ & 637.8 & 4,136 & 8.65 & 628.36 & 629.17 & 0.81 \\
\hline WAK & $33,614.0$ & 555.0 & 4,487 & 7.98 & 631.52 & 632.53 & 1.00 \\
\hline WAL & $34,207.3$ & 217.8 & 2,570 & 13.93 & 634.02 & 634.75 & 0.73 \\
\hline
\end{tabular}


Table 4-1. Results of the floodway analysis for the White River in Bethel, Stockbridge, and Rochester, Vermont, and the Tweed River in Stockbridge and Pittsfield, Vermont.-Continued

[Cross sections with identifiers are shown in appendix 5. ft, feet; $\mathrm{ft}^{2}$, square feet; ft/s, feet per second; NAVD 88, North American Vertical Datum of 1988]

\begin{tabular}{|c|c|c|c|c|c|c|c|}
\hline \multirow{2}{*}{$\begin{array}{l}\text { Cross-section } \\
\text { indentifier }\end{array}$} & \multirow{2}{*}{$\begin{array}{c}\text { River station } \\
\text { (ft) }\end{array}$} & \multicolumn{3}{|c|}{ Floodway } & \multicolumn{3}{|c|}{ Water-surface elevation } \\
\hline & & $\begin{array}{c}\text { Width } \\
\text { (ft) }\end{array}$ & $\begin{array}{c}\text { Section area } \\
\left(\mathrm{ft}^{2}\right)\end{array}$ & $\begin{array}{c}\text { Mean velocity } \\
(\mathrm{ft} / \mathrm{s})\end{array}$ & $\begin{array}{l}\text { Without floodway } \\
\text { (ft, NAVD 88) }\end{array}$ & $\begin{array}{l}\text { With floodway } \\
\text { (ft, NAVD 88) }\end{array}$ & $\begin{array}{c}\text { Increase } \\
\text { (ft) }\end{array}$ \\
\hline \multicolumn{8}{|c|}{ White River-Continued } \\
\hline & $34,386.7$ & \multicolumn{6}{|c|}{ Bridge Street Bridge, Stockbridge, VT } \\
\hline WAM & $34,544.5$ & 233.4 & 3,922 & 9.13 & 639.49 & 639.62 & 0.13 \\
\hline WAN & $35,540.3$ & 210.0 & 2,972 & 12.05 & 642.28 & 642.41 & 0.13 \\
\hline WAO & $36,235.1$ & 181.4 & 2,707 & 13.23 & 646.21 & 646.24 & 0.04 \\
\hline WAP & $37,540.0$ & 203.6 & 2,959 & 12.10 & 654.45 & 654.45 & 0.00 \\
\hline WAQ & $38,127.6$ & 318.2 & 4,405 & 8.13 & 657.83 & 657.83 & 0.00 \\
\hline WAR & $39,358.9$ & 302.8 & 2,643 & 13.55 & 661.92 & 661.92 & 0.00 \\
\hline WAS & $39,731.5$ & 250.9 & 2,534 & 14.13 & 665.46 & 665.46 & 0.00 \\
\hline WAT & $40,937.2$ & 474.5 & 4,275 & 7.74 & 673.20 & 673.20 & 0.00 \\
\hline WAU & $41,537.2$ & 246.9 & 2,666 & 12.41 & 674.69 & 674.70 & 0.02 \\
\hline WAV & $42,592.2$ & 248.3 & 2,935 & 11.28 & 681.86 & 681.86 & 0.00 \\
\hline WAW & $43,184.4$ & 225.6 & 2,853 & 11.60 & 685.32 & 685.32 & 0.00 \\
\hline WAX & $44,378.8$ & 225.5 & 3,211 & 10.31 & 691.03 & 691.03 & 0.00 \\
\hline \multirow[t]{2}{*}{ WAY } & $44,902.5$ & 210.7 & 3,441 & 9.62 & 692.98 & 693.06 & 0.09 \\
\hline & $45,169.4$ & \multicolumn{6}{|c|}{ Blackmer Boulevard, Stockbridge, VT } \\
\hline WAZ & $45,377.7$ & 201.2 & 3,872 & 8.55 & 698.73 & 698.76 & 0.02 \\
\hline WBA & $46,920.0$ & 278.7 & 4,826 & 6.86 & 701.96 & 701.97 & 0.01 \\
\hline WBB & $47,999.7$ & 211.9 & 3,848 & 8.60 & 703.65 & 703.65 & 0.00 \\
\hline WBC & $49,333.0$ & 177.7 & 2,998 & 11.04 & 707.01 & 707.13 & 0.12 \\
\hline WBD & $50,363.7$ & 218.8 & 3,942 & 8.40 & 711.31 & 711.36 & 0.05 \\
\hline WBE & $51,148.5$ & 282.2 & 4,234 & 7.82 & 713.21 & 713.22 & 0.00 \\
\hline WBF & $51,669.3$ & 233.0 & 3,476 & 9.52 & 714.26 & 714.26 & 0.00 \\
\hline WBG & $52,583.0$ & 192.4 & 2,956 & 11.20 & 716.53 & 717.31 & 0.78 \\
\hline WBH & $53,827.1$ & 280.6 & 3,829 & 8.65 & 721.82 & 722.10 & 0.28 \\
\hline WBI & $55,404.0$ & 312.5 & 4,164 & 7.95 & 726.07 & 726.20 & 0.12 \\
\hline WBJ & $56,215.9$ & 199.1 & 2,787 & 11.88 & 728.04 & 728.09 & 0.04 \\
\hline WBK & $57,195.9$ & 230.1 & 3,844 & 8.61 & 733.16 & 733.16 & 0.00 \\
\hline WBL & $58,381.6$ & $1,204.0$ & 13,204 & 2.08 & 735.02 & 735.04 & 0.03 \\
\hline WBM & $59,190.1$ & $1,031.3$ & 9,527 & 2.88 & 735.13 & 735.17 & 0.04 \\
\hline \multirow[t]{2}{*}{ WBN } & $60,094.9$ & 748.6 & 5,488 & 4.99 & 735.71 & 735.73 & 0.02 \\
\hline & $60,248.2$ & \multicolumn{6}{|c|}{ Route 100 Bridge, Stockbridge, VT } \\
\hline WBO & $60,446.0$ & 690.0 & 6,025 & 4.55 & 738.21 & 738.20 & 0.00 \\
\hline WBP & $62,003.0$ & 265.0 & 3,303 & 8.30 & 739.71 & 739.73 & 0.02 \\
\hline WBQ & $62,859.1$ & 531.5 & 6,443 & 4.25 & 741.28 & 741.54 & 0.26 \\
\hline WBR & $63,649.9$ & 629.4 & 6,646 & 4.12 & 741.64 & 742.26 & 0.62 \\
\hline WBS & $64,894.5$ & 497.2 & 5,260 & 5.21 & 742.40 & 743.38 & 0.98 \\
\hline WBT & $66,003.0$ & 475.0 & 4,433 & 6.18 & 743.88 & 744.78 & 0.90 \\
\hline WBU & $66,762.6$ & 374.7 & 3,741 & 7.32 & 744.85 & 745.85 & 1.00 \\
\hline
\end{tabular}


Table 4-1. Results of the floodway analysis for the White River in Bethel, Stockbridge, and Rochester, Vermont, and the Tweed River in Stockbridge and Pittsfield, Vermont.-Continued

[Cross sections with identifiers are shown in appendix 5. ft, feet; $\mathrm{ft}^{2}$, square feet; ft/s, feet per second; NAVD 88, North American Vertical Datum of 1988]

\begin{tabular}{|c|c|c|c|c|c|c|c|}
\hline \multirow{2}{*}{$\begin{array}{l}\text { Cross-section } \\
\text { indentifier }\end{array}$} & \multirow{2}{*}{$\begin{array}{c}\text { River station - } \\
\text { (ft) }\end{array}$} & \multicolumn{3}{|c|}{ Floodway } & \multicolumn{3}{|c|}{ Water-surface elevation } \\
\hline & & $\begin{array}{l}\text { Width } \\
\text { (ft) }\end{array}$ & $\begin{array}{c}\text { Section area } \\
\left(\mathrm{ft}^{2}\right)\end{array}$ & $\begin{array}{c}\text { Mean velocity } \\
(\mathrm{ft} / \mathrm{s})\end{array}$ & $\begin{array}{l}\text { Without floodway } \\
\text { (ft, NAVD 88) }\end{array}$ & $\begin{array}{l}\text { With floodway } \\
\text { (ft, NAVD 88) }\end{array}$ & $\begin{array}{c}\text { Increase } \\
\text { (ft) }\end{array}$ \\
\hline \multicolumn{8}{|c|}{ White River-Continued } \\
\hline WBV & $67,964.9$ & 373.9 & 4,037 & 6.79 & 747.59 & 748.02 & 0.43 \\
\hline WBW & $68,729.2$ & 610.2 & 6,287 & 4.36 & 748.84 & 749.47 & 0.64 \\
\hline WBX & $69,530.0$ & 275.0 & 3,270 & 8.38 & 748.79 & 749.78 & 1.00 \\
\hline WBY & $70,204.6$ & 692.5 & 6,395 & 4.28 & 750.86 & 751.62 & 0.76 \\
\hline WBZ & $71,272.1$ & 730.0 & 6,825 & 4.01 & 751.35 & 752.32 & 0.97 \\
\hline WCA & $72,045.5$ & 579.3 & 3,777 & 7.25 & 751.65 & 752.63 & 0.98 \\
\hline WCB & $72,857.2$ & 295.5 & 2,502 & 10.95 & 754.30 & 754.37 & 0.07 \\
\hline WCC & $73,316.1$ & 322.1 & 3,295 & 8.32 & 756.85 & 756.95 & 0.10 \\
\hline WCD & $74,978.0$ & 490.0 & 4,391 & 6.24 & 760.40 & 761.07 & 0.66 \\
\hline WCE & $75,838.5$ & 439.2 & 3,494 & 7.84 & 761.56 & 762.55 & 0.99 \\
\hline WCF & $76,883.6$ & 660.0 & 5,477 & 5.00 & 764.56 & 765.27 & 0.71 \\
\hline WCG & $77,756.2$ & 465.0 & 3,439 & 7.97 & 765.74 & 766.01 & 0.27 \\
\hline WCH & $79,171.7$ & 212.2 & 3,067 & 8.93 & 769.79 & 770.78 & 0.99 \\
\hline WCI & $80,006.3$ & 260.5 & 3,202 & 8.56 & 772.43 & 772.93 & 0.49 \\
\hline WCJ & $81,084.3$ & 165.8 & 2,247 & 12.19 & 775.04 & 775.30 & 0.27 \\
\hline WCK & $82,177.8$ & 251.2 & 2,758 & 9.94 & 780.03 & 780.08 & 0.05 \\
\hline WCL & $83,205.9$ & 447.0 & 4,940 & 5.24 & 782.86 & 783.20 & 0.34 \\
\hline WCM & $83,689.3$ & 606.6 & 4,507 & 5.75 & 783.10 & 783.47 & 0.37 \\
\hline WCN & $84,934.1$ & 813.1 & 7,699 & 3.36 & 783.87 & 784.81 & 0.94 \\
\hline WCO & $85,500.3$ & 880.2 & 7,702 & 3.36 & 784.11 & 785.08 & 0.97 \\
\hline WCP & $87,066.9$ & 474.9 & 4,051 & 6.39 & 784.96 & 785.87 & 0.91 \\
\hline WCQ & $88,108.9$ & 667.8 & 5,572 & 4.65 & 787.06 & 787.74 & 0.67 \\
\hline WCR & $89,193.4$ & 945.0 & 6,581 & 3.94 & 787.76 & 788.75 & 0.99 \\
\hline \multirow[t]{2}{*}{ WCS } & $90,430.2$ & 440.0 & 2,988 & 8.67 & 789.31 & 790.04 & 0.73 \\
\hline & $90,793.6$ & \multicolumn{6}{|c|}{ Liberty Hill Road Bridge, Rochester, VT } \\
\hline WCT & $91,069.4$ & 657.8 & 6,051 & 4.28 & 795.09 & 795.73 & 0.64 \\
\hline WCU & $92,596.5$ & 660.0 & 4,989 & 5.19 & 796.32 & 797.16 & 0.84 \\
\hline WCV & $93,698.8$ & 560.0 & 4,277 & 6.06 & 797.95 & 798.95 & 1.00 \\
\hline WCW & $95,416.5$ & 297.6 & 3,675 & 7.05 & 801.43 & 801.98 & 0.56 \\
\hline WCX & $96,152.6$ & 875.0 & 6,455 & 4.01 & 802.81 & 803.44 & 0.63 \\
\hline WCY & $97,333.4$ & 690.0 & 5,328 & 4.86 & 804.48 & 804.93 & 0.45 \\
\hline WCZ & $98,577.8$ & 458.0 & 3,352 & 7.73 & 807.29 & 808.23 & 0.94 \\
\hline \multirow[t]{2}{*}{ WDA } & $99,224.9$ & 243.3 & 2,569 & 10.08 & 811.67 & 812.67 & 1.00 \\
\hline & $99,327.5$ & \multicolumn{6}{|c|}{ State Garage Road, Rochester, VT } \\
\hline WDB & $99,466.8$ & 184.3 & 2,733 & 9.48 & 816.75 & 816.74 & 0.00 \\
\hline WDC & $100,388.2$ & 945.3 & 5,381 & 4.81 & 819.87 & 820.08 & 0.21 \\
\hline WDD & $101,102.7$ & 894.9 & 8,438 & 2.31 & 821.02 & 821.20 & 0.18 \\
\hline WDE & $101,877.9$ & 345.5 & 2,921 & 6.68 & 821.03 & 821.20 & 0.16 \\
\hline
\end{tabular}


Table 4-1. Results of the floodway analysis for the White River in Bethel, Stockbridge, and Rochester, Vermont, and the Tweed River in Stockbridge and Pittsfield, Vermont.-Continued

[Cross sections with identifiers are shown in appendix 5. ft, feet; $\mathrm{ft}^{2}$, square feet; ft/s, feet per second; NAVD 88, North American Vertical Datum of 1988]

\begin{tabular}{|c|c|c|c|c|c|c|c|}
\hline \multirow{2}{*}{$\begin{array}{l}\text { Cross-section } \\
\text { indentifier }\end{array}$} & \multirow{2}{*}{$\begin{array}{l}\text { River station } \\
\text { (ft) }\end{array}$} & \multicolumn{3}{|c|}{ Floodway } & \multicolumn{3}{|c|}{ Water-surface elevation } \\
\hline & & $\begin{array}{l}\text { Width } \\
\text { (ft) }\end{array}$ & $\begin{array}{c}\text { Section area } \\
\left(\mathrm{ft}^{2}\right)\end{array}$ & $\begin{array}{l}\text { Mean velocity } \\
\text { (ft/s) }\end{array}$ & $\begin{array}{l}\text { Without floodway } \\
\text { (ft, NAVD 88) }\end{array}$ & $\begin{array}{l}\text { With floodway } \\
\text { (ft, NAVD 88) }\end{array}$ & $\begin{array}{c}\text { Increase } \\
\text { (ft) }\end{array}$ \\
\hline \multicolumn{8}{|c|}{ White River-Continued } \\
\hline & $101,991.7$ & \multicolumn{6}{|c|}{ Route 73 Bridge, Rochester, VT (Temporary Structure) } \\
\hline WDF & $102,206.0$ & 348.0 & 3,635 & 5.36 & 824.06 & 824.06 & 0.00 \\
\hline WDG & $103,340.7$ & 290.0 & 2,715 & 7.18 & 825.55 & 825.67 & 0.12 \\
\hline WDH & $104,059.3$ & 430.0 & 3,281 & 5.94 & 827.64 & 828.24 & 0.60 \\
\hline WDI & $104,247.9$ & 390.0 & 4,353 & 4.48 & 827.95 & 828.89 & 0.94 \\
\hline WDJ & $105,584.0$ & 504.0 & 4,713 & 4.14 & 829.23 & 830.24 & 1.00 \\
\hline WDK & $106,136.2$ & 639.4 & 6,024 & 3.24 & 829.71 & 830.67 & 0.96 \\
\hline WDL & $106,983.8$ & 629.1 & 4,533 & 4.30 & 829.99 & 830.94 & 0.95 \\
\hline \multirow[t]{2}{*}{ WDM } & $108,075.9$ & 499.8 & 3,267 & 5.97 & 831.58 & 832.45 & 0.88 \\
\hline & $108,175.3$ & \multicolumn{6}{|c|}{ River Brook Drive, Rochester, VT } \\
\hline WDN & $108,255.4$ & 580.0 & 4,185 & 4.66 & 832.49 & 833.47 & 0.98 \\
\hline WDO & $109,156.2$ & 243.5 & 2,234 & 8.19 & 834.07 & 834.76 & 0.69 \\
\hline \multicolumn{8}{|c|}{ Tweed River } \\
\hline TA & 680.3 & 300.4 & 1,552 & 5.47 & 729.86 & 730.04 & 0.18 \\
\hline TB & $1,197.1$ & 137.0 & 1,181 & 7.19 & 731.42 & 731.60 & 0.17 \\
\hline $\mathrm{TC}$ & $1,734.9$ & 142.1 & 913 & 9.30 & 733.62 & 733.77 & 0.15 \\
\hline $\mathrm{TD}$ & $2,345.3$ & 372.7 & 1,551 & 5.47 & 739.36 & 740.00 & 0.64 \\
\hline \multirow[t]{2}{*}{$\mathrm{TE}$} & $3,113.3$ & 127.8 & 1,208 & 7.03 & 742.41 & 743.40 & 0.99 \\
\hline & $3,292.3$ & \multicolumn{6}{|c|}{ Route 107 Bridge, Stockbridge, VT } \\
\hline $\mathrm{TF}$ & $3,530.0$ & 215.0 & 1,442 & 5.89 & 744.43 & 745.00 & 0.58 \\
\hline TG & $4,392.2$ & 315.0 & 1,576 & 5.17 & 746.25 & 747.15 & 0.89 \\
\hline $\mathrm{TH}$ & $5,104.6$ & 260.0 & 1,279 & 6.36 & 749.55 & 749.79 & 0.25 \\
\hline \multirow[t]{2}{*}{ TI } & $5,762.3$ & 356.9 & 1,262 & 6.45 & 751.91 & 752.83 & 0.92 \\
\hline & $5,852.9$ & \multicolumn{6}{|c|}{ South Hill Road Bridge, Stockbridge, VT } \\
\hline $\mathrm{TJ}$ & $5,905.6$ & 332.8 & 1,860 & 4.38 & 754.53 & 755.02 & 0.49 \\
\hline TK & $7,156.5$ & 288.3 & 1,378 & 5.91 & 756.42 & 757.41 & 0.99 \\
\hline $\mathrm{TL}$ & $7,890.0$ & 189.5 & 812 & 10.03 & 760.45 & 760.44 & 0.00 \\
\hline $\mathrm{TM}$ & $8,811.4$ & 244.4 & 1,395 & 5.83 & 764.84 & 765.81 & 0.97 \\
\hline $\mathrm{TN}$ & $9,850.4$ & 245.1 & 1,602 & 5.08 & 768.63 & 769.08 & 0.45 \\
\hline TO & $10,376.2$ & 462.1 & 1,988 & 4.09 & 770.60 & 770.89 & 0.29 \\
\hline ТP & $10,812.2$ & 421.1 & 1,621 & 5.02 & 773.04 & 773.31 & 0.26 \\
\hline TQ & $11,403.6$ & 155.0 & 926 & 8.79 & 776.14 & 776.13 & 0.00 \\
\hline $\mathrm{TR}$ & $12,443.2$ & 108.0 & 899 & 9.06 & 781.47 & 781.83 & 0.36 \\
\hline TS & $13,029.2$ & 107.7 & 730 & 11.14 & 785.81 & 785.93 & 0.12 \\
\hline $\mathrm{TT}$ & $13,642.1$ & 149.7 & 1,201 & 6.78 & 789.80 & 790.66 & 0.86 \\
\hline TU & $14,410.6$ & 162.7 & 1,178 & 6.91 & 792.74 & 793.73 & 0.99 \\
\hline TV & $14,961.6$ & 326.6 & 1,909 & 3.77 & 795.98 & 796.44 & 0.46 \\
\hline TW & $15,453.5$ & 312.5 & 1,029 & 6.99 & 797.22 & 797.87 & 0.65 \\
\hline $\mathrm{TX}$ & $15,807.7$ & 300.0 & 1,455 & 4.94 & 800.77 & 801.16 & 0.38 \\
\hline
\end{tabular}


Table 4-1. Results of the floodway analysis for the White River in Bethel, Stockbridge, and Rochester, Vermont, and the Tweed River in Stockbridge and Pittsfield, Vermont.-Continued

[Cross sections with identifiers are shown in appendix 5. ft, feet; $\mathrm{ft}^{2}$, square feet; ft/s, feet per second; NAVD 88, North American Vertical Datum of 1988]

\begin{tabular}{|c|c|c|c|c|c|c|c|}
\hline \multirow{2}{*}{$\begin{array}{l}\text { Cross-section } \\
\text { indentifier }\end{array}$} & \multirow{2}{*}{$\begin{array}{l}\text { River station - } \\
\text { (ft) }\end{array}$} & \multicolumn{3}{|c|}{ Floodway } & \multicolumn{3}{|c|}{ Water-surface elevation } \\
\hline & & $\begin{array}{l}\text { Width } \\
\text { (ft) }\end{array}$ & $\begin{array}{c}\text { Section area } \\
\left(\mathrm{ft}^{2}\right)\end{array}$ & $\begin{array}{c}\text { Mean velocity } \\
\text { (ft/s) }\end{array}$ & $\begin{array}{l}\text { Without floodway } \\
\text { (ft, NAVD 88) }\end{array}$ & $\begin{array}{l}\text { With floodway } \\
\text { (ft, NAVD 88) }\end{array}$ & $\begin{array}{c}\text { Increase } \\
\text { (ft) }\end{array}$ \\
\hline \multicolumn{8}{|c|}{ Tweed River-Continued } \\
\hline TY & $16,140.3$ & 157.8 & 860 & 8.36 & 802.14 & 802.19 & 0.04 \\
\hline $\mathrm{TZ}$ & $16,607.6$ & 143.0 & 1,021 & 7.04 & 805.22 & 805.95 & 0.73 \\
\hline TAA & $17,462.7$ & 212.1 & 911 & 7.90 & 810.90 & 811.90 & 1.00 \\
\hline TAB & $18,282.1$ & 229.2 & 1,093 & 6.58 & 819.06 & 820.06 & 1.00 \\
\hline TAC & $18,618.8$ & 220.6 & 1,120 & 6.42 & 820.83 & 821.68 & 0.85 \\
\hline TAD & $19,102.6$ & 146.9 & 778 & 9.24 & 823.25 & 824.04 & 0.79 \\
\hline \multirow[t]{2}{*}{ TAE } & $19,676.6$ & 320.0 & 1,209 & 5.64 & 828.36 & 828.71 & 0.35 \\
\hline & $19,718.8$ & \multicolumn{6}{|c|}{ Snowmobile Trail Bridge, Pittsfield, VT } \\
\hline TAF & $19,769.2$ & 475.0 & 1,987 & 3.43 & 830.23 & 830.33 & 0.10 \\
\hline TAG & $20,329.8$ & 237.5 & 797 & 8.56 & 833.54 & 833.53 & 0.00 \\
\hline \multirow[t]{2}{*}{ TAH } & $20,632.9$ & 270.0 & 818 & 4.33 & 837.57 & 837.57 & 0.00 \\
\hline & $20,682.5$ & \multicolumn{6}{|c|}{ Paramenter Place Bridge, Pittsfield, VT } \\
\hline TAI & $20,720.3$ & 243.1 & 1,065 & 3.32 & 839.56 & 839.57 & 0.01 \\
\hline TAJ & $21,126.8$ & 369.6 & 816 & 4.34 & 840.64 & 840.64 & 0.00 \\
\hline TAK & $21,351.5$ & 292.2 & 725 & 5.39 & 842.15 & 842.24 & 0.08 \\
\hline TAL & $21,635.0$ & 102.7 & 426 & 9.17 & 844.46 & 844.93 & 0.46 \\
\hline \multirow[t]{2}{*}{ TAM } & $21,989.4$ & 74.5 & 574 & 6.82 & 847.24 & 848.04 & 0.80 \\
\hline & $22,037.5$ & \multicolumn{6}{|c|}{ Covered Bridge (Private), Pittsfield, VT } \\
\hline TAN & $22,110.8$ & 62.0 & 685 & 5.71 & 851.37 & 851.89 & 0.52 \\
\hline \multirow[t]{2}{*}{ TAO } & $22,267.8$ & 134.0 & 978 & 4.00 & 851.59 & 852.37 & 0.78 \\
\hline & $22,360.7$ & \multicolumn{6}{|c|}{ Tweed River Drive, Pittsfield, VT } \\
\hline TAP & $22,449.8$ & 216.0 & 1,257 & 3.11 & 852.34 & 853.33 & 0.98 \\
\hline TAQ & $22,964.7$ & 240.0 & 662 & 5.91 & 853.85 & 854.48 & 0.63 \\
\hline TAR & $23,478.9$ & 256.0 & 880 & 4.44 & 858.10 & 859.10 & 1.00 \\
\hline TAS & $24,387.6$ & 113.8 & 564 & 6.93 & 864.98 & 865.24 & 0.26 \\
\hline TAT & $24,866.1$ & 112.2 & 546 & 7.16 & 868.91 & 869.92 & 1.00 \\
\hline TAU & $25,341.0$ & 98.3 & 541 & 7.23 & 874.13 & 874.15 & 0.02 \\
\hline TAV & $25,930.4$ & 97.6 & 559 & 6.99 & 878.08 & 878.48 & 0.40 \\
\hline \multirow[t]{2}{*}{ TAW } & $26,680.5$ & 80.7 & 438 & 8.94 & 884.58 & 884.87 & 0.29 \\
\hline & $26,769.2$ & \multicolumn{6}{|c|}{ Route 100 Bridge, Pittsfield, VT (Temporary Structure) } \\
\hline TAX & $26,883.3$ & 165.0 & 838 & 4.67 & 888.56 & 888.63 & 0.08 \\
\hline TAY & $27,560.7$ & 83.7 & 335 & 11.68 & 894.10 & 894.91 & 0.82 \\
\hline TAZ & $28,018.4$ & 162.0 & 784 & 4.99 & 901.00 & 901.76 & 0.76 \\
\hline TBA & $28,645.7$ & 110.5 & 391 & 9.99 & 907.67 & 907.73 & 0.06 \\
\hline TBB & $29,049.6$ & 187.0 & 663 & 5.90 & 914.91 & 915.00 & 0.08 \\
\hline TBC & $29,466.3$ & 87.6 & 420 & 6.45 & 918.80 & 918.83 & 0.03 \\
\hline TBD & $30,030.2$ & 64.6 & 322 & 9.57 & 925.73 & 925.77 & 0.04 \\
\hline
\end{tabular}


Table 4-1. Results of the floodway analysis for the White River in Bethel, Stockbridge, and Rochester, Vermont, and the Tweed River in Stockbridge and Pittsfield, Vermont.-Continued

[Cross sections with identifiers are shown in appendix 5. ft, feet; $\mathrm{ft}^{2}$, square feet; ft/s, feet per second; NAVD 88, North American Vertical Datum of 1988]

\begin{tabular}{|c|c|c|c|c|c|c|c|}
\hline \multirow{2}{*}{$\begin{array}{l}\text { Cross-section } \\
\text { indentifier }\end{array}$} & \multirow{2}{*}{$\begin{array}{c}\text { River station - } \\
\text { (ft) }\end{array}$} & \multicolumn{3}{|c|}{ Floodway } & \multicolumn{3}{|c|}{ Water-surface elevation } \\
\hline & & $\begin{array}{l}\text { Width } \\
\text { (ft) }\end{array}$ & $\begin{array}{c}\text { Section area } \\
\left(\mathrm{ft}^{2}\right)\end{array}$ & $\begin{array}{c}\text { Mean velocity } \\
(\mathrm{ft} / \mathrm{s})\end{array}$ & $\begin{array}{c}\text { Without floodway } \\
\text { (ft, NAVD 88) }\end{array}$ & $\begin{array}{l}\text { With floodway } \\
\text { (ft, NAVD 88) }\end{array}$ & $\begin{array}{c}\text { Increase } \\
\text { (ft) }\end{array}$ \\
\hline \multicolumn{8}{|c|}{ Tweed River-Continued } \\
\hline & $30,063.9$ & \multicolumn{6}{|c|}{ Bakers Road Bridge, Pittsfield, VT } \\
\hline TBE & $30,109.5$ & 123.0 & 978 & 2.77 & 931.09 & 931.56 & 0.47 \\
\hline TBF & $30,420.9$ & 158.0 & 743 & 3.65 & 931.42 & 931.95 & 0.53 \\
\hline TBG & $30,887.2$ & 204.0 & 397 & 6.82 & 935.75 & 935.94 & 0.19 \\
\hline $\mathrm{TBH}$ & $31,222.5$ & 371.4 & 977 & 2.78 & 939.41 & 939.66 & 0.25 \\
\hline TBI & $31,558.9$ & 178.0 & 552 & 4.91 & 941.27 & 941.28 & 0.01 \\
\hline TBJ & $31,992.3$ & 210.3 & 632 & 4.29 & 945.05 & 945.04 & 0.00 \\
\hline TBK & $32,569.5$ & 146.6 & 347 & 7.80 & 953.48 & 953.48 & 0.00 \\
\hline TBL & $33,063.3$ & 137.5 & 562 & 4.83 & 960.73 & 960.85 & 0.12 \\
\hline TBM & $33,549.2$ & 108.4 & 310 & 8.73 & 966.66 & 966.76 & 0.10 \\
\hline \multirow[t]{2}{*}{ TBN } & $33,851.3$ & 182.0 & 634 & 4.27 & 971.02 & 971.37 & 0.34 \\
\hline & $33,919.7$ & \multicolumn{6}{|c|}{ Stonewood Crossing Bridge, Pittsfield, VT } \\
\hline TBO & $33,987.0$ & 281.1 & 1,076 & 2.52 & 972.77 & 973.76 & 0.99 \\
\hline TBP & $34,322.5$ & 102.0 & 292 & 9.30 & 976.28 & 976.39 & 0.10 \\
\hline TBQ & $34,766.2$ & 66.8 & 358 & 7.58 & 983.28 & 983.74 & 0.45 \\
\hline TBR & $35,175.3$ & 62.0 & 300 & 9.03 & 988.34 & 988.58 & 0.23 \\
\hline TBS & $35,466.7$ & 71.9 & 221 & 8.24 & 993.97 & 994.46 & 0.49 \\
\hline \multirow[t]{2}{*}{ TBT } & $35,665.3$ & 105.0 & 336 & 5.41 & 997.52 & 998.52 & 1.00 \\
\hline & $35,719.8$ & \multicolumn{6}{|c|}{ Private Drive Bridge, Pittsfield, VT } \\
\hline TBU & $35,768.7$ & 73.0 & 339 & 5.37 & 999.94 & $1,000.63$ & 0.69 \\
\hline TBV & $35,985.8$ & 65.2 & 188 & 9.70 & $1,002.67$ & $1,002.67$ & 0.00 \\
\hline TBW & $36,320.7$ & 249.1 & 488 & 3.73 & $1,009.26$ & $1,009.26$ & 0.00 \\
\hline TBX & $36,704.8$ & 105.9 & 248 & 7.35 & $1,013.85$ & $1,013.85$ & 0.00 \\
\hline TBY & $37,044.7$ & 86.3 & 277 & 6.58 & $1,020.25$ & $1,020.25$ & 0.00 \\
\hline TBZ & $37,456.6$ & 82.1 & 204 & 8.94 & $1,029.68$ & $1,029.68$ & 0.00 \\
\hline \multirow[t]{2}{*}{ TCA } & $37,853.5$ & 53.7 & 273 & 6.66 & $1,036.66$ & $1,036.84$ & 0.18 \\
\hline & $37,885.1$ & \multicolumn{6}{|c|}{ Fellows Lane Bridge, Pittsfield, VT } \\
\hline TCB & $37,938.5$ & 84.6 & 472 & 3.85 & $1,039.46$ & $1,039.47$ & 0.01 \\
\hline TCC & $38,166.3$ & 78.9 & 195 & 9.31 & $1,042.07$ & $1,042.07$ & 0.00 \\
\hline \multirow[t]{2}{*}{$\mathrm{TCD}$} & $38,407.2$ & 62.3 & 242 & 7.52 & $1,047.89$ & $1,047.89$ & 0.00 \\
\hline & $38,435.7$ & \multicolumn{6}{|c|}{ Hadley Lane Bridge, Pittsfield, VT } \\
\hline TCE & $38,464.3$ & 140.2 & 390 & 4.67 & $1,050.75$ & $1,050.75$ & 0.00 \\
\hline TCF & $38,956.8$ & 76.8 & 222 & 8.21 & $1,057.40$ & $1,057.83$ & 0.42 \\
\hline TCG & $39,270.5$ & 51.8 & 281 & 6.48 & $1,064.43$ & $1,064.62$ & 0.19 \\
\hline $\mathrm{TCH}$ & $39,893.2$ & 76.2 & 328 & 5.54 & $1,071.65$ & $1,071.65$ & 0.00 \\
\hline TCI & $40,419.1$ & 50.0 & 210 & 8.65 & $1,079.55$ & $1,079.96$ & 0.41 \\
\hline TCJ & $40,841.6$ & 64.9 & 281 & 6.48 & $1,088.24$ & $1,088.65$ & 0.41 \\
\hline TCK & $41,303.3$ & 46.5 & 168 & 10.85 & $1,101.91$ & $1,101.91$ & 0.00 \\
\hline TCL & $41,636.3$ & 39.0 & 274 & 6.64 & $1,108.66$ & $1,109.20$ & 0.54 \\
\hline
\end{tabular}


Table 4-1. Results of the floodway analysis for the White River in Bethel, Stockbridge, and Rochester, Vermont, and the Tweed River in Stockbridge and Pittsfield, Vermont.-Continued

[Cross sections with identifiers are shown in appendix 5. ft, feet; $\mathrm{ft}^{2}$, square feet; $\mathrm{ft} / \mathrm{s}$, feet per second; NAVD 88, North American Vertical Datum of 1988]

\begin{tabular}{|c|c|c|c|c|c|c|c|}
\hline \multirow{2}{*}{$\begin{array}{l}\text { Cross-section } \\
\text { indentifier }\end{array}$} & \multirow{2}{*}{$\begin{array}{c}\text { River station } \\
\text { (ft) }\end{array}$} & \multicolumn{3}{|c|}{ Floodway } & \multicolumn{3}{|c|}{ Water-surface elevation } \\
\hline & & $\begin{array}{l}\text { Width } \\
\text { (ft) }\end{array}$ & $\begin{array}{c}\text { Section area } \\
\left(\mathrm{ft}^{2}\right)\end{array}$ & $\begin{array}{c}\text { Mean velocity } \\
(\mathrm{ft} / \mathrm{s})\end{array}$ & $\begin{array}{l}\text { Without floodway } \\
\text { (ft, NAVD 88) }\end{array}$ & $\begin{array}{l}\text { With floodway } \\
\text { (ft, NAVD 88) }\end{array}$ & $\begin{array}{c}\text { Increase } \\
\text { (ft) }\end{array}$ \\
\hline \multicolumn{8}{|c|}{ Tweed River-Continued } \\
\hline & $41,667.9$ & \multicolumn{6}{|c|}{ Leigh Kelley Drive Bridge, Pittsfield, VT } \\
\hline TCM & $41,697.0$ & 56.0 & 329 & 5.53 & $1,109.56$ & $1,110.52$ & 0.97 \\
\hline \multirow[t]{2}{*}{$\mathrm{TCN}$} & $41,745.8$ & 69.0 & 289 & 6.30 & $1,110.08$ & $1,110.85$ & 0.77 \\
\hline & & \multicolumn{6}{|c|}{ Tweed River Bypass } \\
\hline BA & 70.3 & 52.9 & 173 & 2.14 & 832.32 & 832.57 & 0.25 \\
\hline $\mathrm{BB}$ & 173.7 & 77.3 & 68.8 & 5.38 & 837.70 & 837.79 & 0.09 \\
\hline $\mathrm{BC}$ & 261.9 & 80.0 & 227 & 1.63 & 838.67 & 839.08 & 0.42 \\
\hline $\mathrm{BD}$ & 379.3 & 50.1 & 59.5 & 6.22 & 840.52 & 840.54 & 0.02 \\
\hline
\end{tabular}

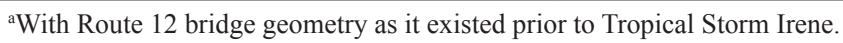

${ }^{b}$ With Route 73 bridge geometry as it existed prior to Tropical Storm Irene.

${ }^{\mathrm{c} B a c k w a t e r}$ from White River.

dPeak water-surface without bypass diversion. 


\section{Appendix 5. Results of the Floodway Analysis for the White River Modified for the Planned Route 73 Bridge in Rochester, Vermont}


Table 5-1. Results of the floodway analysis for the White River modified for the planned Route 73 bridge in Rochester, Vermont.

[Cross sections with identifiers are shown in appendix 5. ft, feet; $\mathrm{ft}^{2}$, square feet; $\mathrm{ft} / \mathrm{s}$, feet per second; NAVD 88, North American Vertical Datum of 1988; VT, Vermont]

\begin{tabular}{|c|c|c|c|c|c|c|c|}
\hline \multirow{2}{*}{$\begin{array}{l}\text { Cross-section } \\
\text { indentifier }\end{array}$} & \multirow{2}{*}{$\begin{array}{c}\text { River station } \\
\text { (ft) }\end{array}$} & \multicolumn{3}{|c|}{ Floodway } & \multicolumn{3}{|c|}{ Water-surface elevation } \\
\hline & & $\begin{array}{c}\text { Width } \\
\text { (ft) }\end{array}$ & $\begin{array}{c}\text { Section area } \\
\left(\mathrm{ft}^{2}\right)\end{array}$ & $\begin{array}{c}\text { Mean velocity } \\
\text { (ft/s) }\end{array}$ & $\begin{array}{l}\text { Without floodway } \\
\text { (ft, NAVD 88) }\end{array}$ & $\begin{array}{l}\text { With floodway } \\
\text { (ft, NAVD 88) }\end{array}$ & $\begin{array}{c}\text { Increase } \\
\text { (ft) }\end{array}$ \\
\hline WDB & $99,466.8$ & 184.3 & 2,733 & 9.48 & 816.75 & 816.74 & 0.00 \\
\hline WDC & $100,388.2$ & 495.5 & 4,038 & 6.41 & 819.87 & 820.13 & 0.26 \\
\hline WDE & $101,991.7$ & \multicolumn{6}{|c|}{ Route 73 Bridge, Rochester, VT (Planned Structure) } \\
\hline WDF & $102,206.0$ & 343.0 & 4,102 & 4.75 & 825.52 & 825.53 & 0.01 \\
\hline WDG & $103,340.7$ & 265.0 & 2,785 & 7.00 & 826.40 & 826.44 & 0.04 \\
\hline WDH & $104,059.3$ & 430.0 & 3,464 & 5.63 & 828.05 & 828.66 & 0.62 \\
\hline WDL & $106,983.8$ & 630.0 & 4,644 & 4.20 & 830.17 & 831.11 & 0.94 \\
\hline \multirow[t]{2}{*}{ WDM } & $108,075.9$ & 500.0 & 3,306 & 5.90 & 831.64 & 832.53 & 0.89 \\
\hline & $108,175.3$ & \multicolumn{6}{|c|}{ River Brook Drive, Rochester, VT } \\
\hline
\end{tabular}


For more information concerning this report, contact: Director, New England Water Science Center

U.S. Geological Survey

331 Commerce Way, Suite 2

Pembroke, NH 03275

dc_nweng@usgs.gov

or visit our Web site at:

http://nh.water.usgs.gov

Publishing support by:

The Pembroke and West Trenton Publishing Service Centers. 


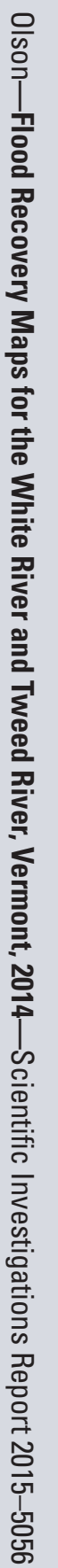

